\title{
PENGEMBANGAN PERANGKAT PEMBELAJARAN MENGGUNAKAN PENDEKATAN SAINTIFIK UNTUK MENINGKATKAN HASIL BELAJAR DAN MELATIHKAN KETERAMPILAN BERPIKIR KRITIS SISWA
}

\author{
Ngadiman $^{1)}$, Prabowo' ${ }^{2)}$, Raharjo ${ }^{3)}$ \\ ${ }^{1)}$ Mahasiswa Program Studi Pendidikan Dasar, Program Pascasarjana Universitas Negeri Surabaya \\ ${ }^{2), 3)}$ Dosen Pascasarjana Prodi Pendidikan Sains Univesrtitas Negeri Surabaya \\ E-mail: ngadiman_af80@yahoo.co.id
}

\begin{abstract}
This research development aims to determine the quality (validity, practicality, and effectiveness) of Physics Learning Material using Scientific Approach to Practice Students's Critical Thinking Skills in subject of fluid for student class XI Senior High School State 1 Batu Sopang. This research was implemented in two phases, namely the development of devices to follow the Morrison, Ross, Kalman, \& Kemp's design, continued implementation of the learning in the classroom using Pre- and PostDesign from Prunckun. The results showed that the developed device has a valid, practical, and effective. Valid visible from the validator assessment of the lesson plan RPP; student worksheets; students books achievement test; learning outcomes assessment instruments knowledge, performance, attitude, and critical thinking skills. Practical seen from the percentage feasibility study stage is $100 \%$; scores feasibility study in class XI-IA-1 is 3.71; XI-IA-2 3.72; and XI-IA-3 3.67; activities that support the scientific approach more dominant in learning and irrelevant activity has decreased every meeting; students responded positively to the process of learning and using a scientific approach that has been developed. Effective seen from individual mastery of knowledge learning outcomes of students of class XI-IA-1 is $88.00 \%$; XI-IA-2 92.00\%; XI- IA-3 87.00\%; individual mastery of performance and attitude learning outcomes of students each class is $100 \%$; all students to increase critical thinking skills. Obstacles encountered in this study is times less efficient in guiding the students carry out experiments and practice critical thinking skills. The research showed that the physics learning material using scientific approach has valid, practical, and effective to improve learning outcomes and practice critical thinking skills.
\end{abstract}

Keywords: Physics learning, scientific approach, learning outcomes, critical thinking skills

Abstrak: Penelitian pengembangan ini bertujuan untuk mengetahui kualitas (validitas, kepraktisan, dan keefektifan) perangkat pembelajaran fisika melalui pendekatan saintifik untuk meningkatkan hasil belajar dan melatihkan keterampilan berpikir kritis pada materi fluida untuk siswa kelas XI SMA Negeri 1 Batu Sopang. Penelitian ini dilaksanakan dalam dua tahap, yaitu pengembangan perangkat mengikuti rancangan Morrison, Ross, Kalman, \& Kemp, dilanjutkan implementasi perangkat pembelajaran di kelas menggunakan Pre- and Post-Design dari Prunckun. Hasil penelitian menunjukkan bahwa perangkat yang dikembangkan telah valid, praktis, dan efektif. Valid terlihat dari penilaian validator terhadap RPP; LKS; buku siswa; instrumen penilaian hasil belajar pengetahuan, keterampilan, sikap, dan keterampilan berpikir kritis. Praktis terlihat dari persentase keterlaksanaan tahapan pembelajaran sebesar 100\%; skor keterlaksanaan pembelajaran di kelas XI-IA-1 sebesar 3,71; XI-IA-2 3,72; dan XI-IA-3 3,67; aktivitas yang mendukung pendekatan saintifik lebih dominan dalam pembelajaran dan aktivitas tidak relevan mengalami penurunan setiap pertemuan; siswa memberikan respon positif terhadap perangkat dan proses pembelajaran menggunakan pendekatan saintifik yang telah dikembangkan. Efektif terlihat dari ketuntasan individual hasil belajar pengetahuan siswa kelas XI-IA-1 sebesar 88,00\%; XI-IA-2 92,00\%; XI-IA-3 87,00\%; ketuntasan individual hasil belajar keterampilan dan sikap siswa setiap kelas sebesar $100 \%$; semua siswa mengalami peningkatan keterampilan berpikir kritis. Kendala yang dihadapi dalam penelitian ini adalah kurang efisien waktu dalam membimbing siswa melaksanakan eksperimen dan melatihkan keterampilan berpikir kritis. Hasil penelitian menunjukkan bahwa perangkat pembelajaran fisika menggunakan pendekatan saintifik telah valid, praktis, dan efektif untuk meningkatkan hasil belajar dan melatihkan keterampilan berpikir kritis siswa.

Kata kunci: Pembelajaran Fisika, Pendekatan Saintifik, Hasil Belajar, Keterampilan Berpikir Kritis

\section{PENDAhuluan}

Pendidikan bertujuan untuk mempersiapkan manusia Indonesia agar memiliki kemampuan hidup sebagai pribadi dan warga negara yang beriman, produktif, kreatif, inovatif, dan afektif serta mampu berkontribusi pada kehidupan bermasyarakat, berbangsa, bernegara, dan peradaban dunia. (Depdikbud, 2013). Pendidik merupakan salah satu pelaksana kurikulum, sehingga mempunyai kewajiban dan tanggung jawab untuk mempersiapkan Sumber Daya Manusia (SDM) Indonesia yang berperan bagi negara, bukan beban negara karena tidak produktif, 
kreatif, dan inovatif.

Orientasi pendidikan adalah terjadinya peningkatan dan keseimbangan antara kompetensi sikap (attitude), keterampilan (skill) dan pengetahuan (knowledge). Salah satu hal yang menjadi alasan pengembangan Kurikulum 2013 adalah perubahan proses pembelajaran dari siswa diberi tahu menjadi siswa mencari tahu dan proses penilaian dari berbasis output menjadi berbasis proses dan output (Depdikbud, 2013). Berdasarkan orientasi tersebut, berarti proses pembelajaran diharapkan dapat mengkondisikan siswa sebagai manusia seutuhnya, memiliki pengetahuan, keterampilan, dan perilaku yang baik. Pembelajaran juga sebaiknya berpusat pada siswa (student centered) dan penilaian lebih mementingkan proses daripada hanya hasil akhir.

Pada TIMSS (Trends in International Mathematics and Science Study) 2011, Indonesia menempati posisi rata-rata $35 \mathrm{ke}$ atas dari 42 negara. Indonesia mendapatkan rata-rata menjawab benar $13 \%$ di bawah rata-rata internasional $32 \%$, Thailand $22 \%$ dan Malaysia 16\% (Martin, Mullis, Foy, \& Stanco, 2012). TIMSS memberikan memberikan pertanyaanpertanyaan tentang sains terapan pada masyarakat. Soal sains terapan tersebut memilliki ranah pengetahuan tinggi dan memerlukan penalaran (reasoning) yang merupakan salah satu ciri keterampilan berpikir kritis, sehingga Penelitian tersebut menggambarkan bahwa siswa Indonesia masih kurang memahami tentang penerapan konsep-konsep fisika dalam kehidupan sehari-hari dan memahami konsep fisika hanya sebagai sebuah teori. Dalam pembelajaran sains, pendidik sebaiknya lebih menekankan pada proses untuk mendapatkan pengetahuan, mengkondisikan siswa untuk terbiasa mengamati, menanya, menalar, mencoba, dan membentuk bekerja sama untuk mendapatkan pengetahuan, hal tersebut sesuai dengan pendapat Gedgrave (2009) bahwa proses mendapatkan pengetahuan lebih penting daripada produk. Proses tersebut sebagai cara untuk mengeksplorasi kebenaran dan memperoleh pengetahuan, oleh karena itu sebaiknya diberikan pilihan lebih dalam daripada menghafal kumpulan fakta.

Di samping rendahnya penalaran siswa tentang pengusaan konsep, miskonsepsi juga masih sering terjadi dalam pembelajaran, hal tersebut sesuai dengan hasil tes diagnostik miskonsepsi oleh penulis di sekolah ketika menempuh mata kuliah sains/fisika sekolah. Hasil tes tersebut menggambarkan sekitar $44 \%$ siswa mengalami miskonsepsi (Ngadiman, 2013). Miskonsepsi tersebut perlu dikurangi karena berhubungan dengan pemahaman konsep fisika yang berakibat kurang baik bagi perkembangan teknologi dan penerapan konsep fisika dalam kehidupan sehari-hari..

Proses kognitif yang paling banyak dijumpai dalam tujuan-tujuan di bidang pendidikan, yaitu pengetahuan (knowledge), kemudian pemahaman (comprehension) dan penerapan (application), ke proses-proses kognitif yang jarang dijumpai, yakni analisis (analysis), sintesis (synthesis), dan evaluasi (evaluation) (Bloom, Englehart, Furst, Hill, \& Krathwohl, 1956). Hasil belajar fisika secara kognitif di sekolah penulis sudah cukup baik, hal tersebut dibuktikan dengan tingkat ketuntasan beberapa tahun terakhir sekitar $70 \%$ tetapi dari pengamatan dokumen instrumen evaluasi ternyata memiliki ranah kognitif yang masih rendah yaitu mengingat, memahami, dan menerapkan.

Hasil evaluasi keterlaksanaan standar proses oleh penulis di sekolah ditemukan beberapa hal yang perlu menjadi perhatian mengenai pelaksanaan penilaian keterampilan. Pendidik mata pelajaran sains (fisika, kimia dan biologi) masih sangat jarang melaksanakan penilaian ini, yaitu rata-rata hanya 2 sampai 3 kali dalam satu semester. Pendidik juga mengalami kesulitan dalam menyusun perangkat penilaian ini, kesulitan-kesulitan yang dimaksud antara lain cara menentukan kata kerja operasional (KKO) sesuai dengan tingkatan kompetensi pada ranah keterampilan, teknik mengembangkan indikator pencapaian dalam ranah keterampilan, strategi menyiapkan perangkat penilaian dan bahan ujian sesuai karakteristik aspek keterampilan, dan cara melaksanakan penilaian keterampilan secara objektif.

Krathwohl, Bloom, dan Masia (dalam Morrison, Ross, Kalman, \& Kemp, 2011) mengorganisasikan domain afektif dalam lima tingkatan, yaitu menerima (receiving), merespon (responding), menilai (valuing), pengorganisasian (organizing), dan karakterisasi (characterizing). Masalah sikap dirasakan penting oleh semua siswa, namun implementasinya di sekolah penulis masih kurang. Satuan pendidikan dan pendidik masih menganggap bahwa penilaian ini hanya menyangkut kesopanan, kerapian, keramahan, kebersihan, dan kedisiplinan, sedangkan keberhasilan pendidik melaksanakan pembelajaran ranah sikap dan keberhasilan peserta didik mencapai kompetensi sikap perlu dinilai. Oleh karena itu perlu dikembangkan acuan pengembangan perangkat penilaian ranah sikap serta penafsiran hasil pengukurannya.

Pendidik di sekolah penulis ketika MGMP (Musyawah Guru Mata Pelajaran) Kabupaten juga banyak mengeluhkan bagaimana cara: (1) menyajikan media obyek secara nyata sehingga siswa senang dan tertantang, (2) membangkitkan rasa ingin tahu, minat, dan perhatian siswa tentang suatu tema atau topik pembelajaran, (3) membiasakan siswa bernalar atau berpikir yang logis atas fakta yang dapat diobservasi untuk memperoleh simpulan berupa pengetahuan, (4) membiasakan siswa melakukan percobaan, (5) rasa 
kekeluargaan dengan bekerja sama memecahkan masalah yang dihadapi, dan (6) menilai kompetensi inti sikap spiritual, sikap sosial, pengetahuan, dan keterampilan dalam pembelajaran. Pembelajaran dengan mengkondisikan dan memfasilitasi siswa mengamati obyek nyata, membuat pertanyaan, mengumpulkan data untuk menjawab pertanyaan melalui percobaan, menalar untuk mengolah data, dan mengkomunikasikan hasil melalui diskusi serta presentasi diharapkan dapat mengatasi masalah tersebut.

Belajar sepanjang hidup menjadi salah satu kunci dari abad ke-21 karena memenuhi tantangan dunia yang berubah dengan cepat. Paradigma pembelajaran seumur hidup didasarkan pada empat pilar utama yang mendasari pendidikan dan kehidupan yaitu: (1) belajar untuk belajar atau belajar untuk mengetahui (Learning to know) memungkinkan bekerja secara mendalam pada sejumlah mata pelajaran yang dipilih; (2) belajar untuk melakukan (Learning to do), menekankan pada perolehan keterampilan; (3) belajar untuk menjadi (Learning to be), menggunakan kebebasan yang lebih besar dikombinasikan dengan rasa tanggung jawab yang lebih kuat untuk mencapai tujuan bersama; (4) belajar untuk hidup bersama (Learning to live together) penting untuk mengembangkan pemahaman tentang orang lain, menciptakan semangat baru, bersatu menghadapi tantangan di masa depan, dan mengelola konflik secara cerdas dan damai (Tawil \& Cougoureux, 2013).

Pembelajaran diharapkan dapat menjadi wadah bagi siswa untuk memenuhi kebutuhan manusia, mengembangkan kepribadian, menyalurkan ekspresi, menjadikan individu yang berguna bagi keluarga, masyarakat, dan bangsa serta mewujudkan mimpimimpi yang kreatif. Pembelajaran sebaiknya dapat mengkondisikan siswa melakukan dan melatih keterampilan bukan sekedar menerima pengetahuan. Pembelajaan menyiratkan bagaimana cara belajar dengan mengembangkan konsentrasi seseorang, kemampuan memori dan kemampuan berpikir, berpikir dapat ditingkatkan dengan segala macam pengalaman manusia. Pembelajaran atau pendidikan yang disediakan oleh keluarga, masyarakat atau sekolah, sebaiknya mengajarkan siswa untuk memahami orang lain, mendorong semangat empati, dan memiliki efek positif pada perilaku sosial dalam kehidupan.

Pembelajaran merupakan proses saintifik. Karena itu kurikulum 2013 mengamanatkan esensi pendekatan saintifik dalam pembelajaran. Pendekatan saintifik diyakini sebagai titian emas perkembangan dan pengembangan sikap, keterampilan, dan pengetahuan peserta didik. Pendekatan saintifik (scientific appoach) dalam pembelajaran sebagaimana dimaksud meliputi mengamati, menanya, menalar, mencoba, dan membentuk jejaring, mengolah, menyajikan, menyimpulkan, dan mencipta untuk semua mata pelajaran (Depdikbud, 2013)

Pendekatan saintifik membantu siswa untuk mengembangkan kekuatan penalaran, berpikir kritis dan penerapan pengetahuan ilmiah. Pendekatan ini juga membantu dalam mengembangkan sikap positif di antara siswa (Gedgrave, 2009). Pembelajaran melalui pendekatan saintifik (scientific appoach) membiasakan siswa untuk mengamati, menanya, menalar, mencoba, dan membentuk jejaring, mengolah, menyajikan dan menyimpulkan. Hal tersebut sesuai dengan unsur dasar berpikir kritis yang disampaikan oleh Ennis yaitu "the one recomended here has six basic elements: Facus, Reason, Inference, Situation, Clarity, and Overview (FRISCO)" (Ennis, 1996) "We think critically when we rationally evaluate our own or others thinking”. Berpikir kritis adalah secara rasional mengevaluasi pemikiran sendiri atau orang lain (Moore \& Parker, 2012).

Keterampilan berpikir kritis diperlukan dalam setiap langkah-langkah atau tahap-tahap penyelidikan. Setiap aspek dari tahap penyelidikan dapat dilakukan oleh siswa tetapi bisa saja dilakukan dengan cara yang tidak kritis. Sebagai contoh merumuskan masalah dengan cara yang dangkal, gagal mengumpulkan data yang lengkap, prosedur kerja yang digunakan banyak yang bias atau berpikiran tertutup, salah dalam memilih sumber yang kredibel, dan akhirnya menghasilkan kesimpulan yang tidak valid (Bailin, 2002).

Keterampilan berpikir kritis siswa di sekolah masih kurang dan perlu dilatihkan dalam pembelajaran, hal tersebut didukung dengan data hasil pembagian angket tentang keterampilan berpikir kritis kepada 31 siswa salah satu sekolah di Kalimantan Timur. Rincian data hasil pembagian angket tersebut adalah sebagai berikut: pengertian keterampilan berpikir kritis $77 \%$ belum tahu, memahami tentang keterampilan berpikir kritis $84 \%$ belum paham, merumuskan pertanyaan yang mengarahkan untuk menemukan jawaban $71 \%$ belum mampu, menganalisis kelemahan dalam mengumpulkan data/informasi $74 \%$ belum mampu, merumuskan hipotesis $71 \%$ belum mampu, membuat kesimpulan $71 \%$ belum mampu, mengevaluasi kesimpulan $87 \%$ belum mampu, mendefinisikan istilah $81 \%$ belum mampu, memberikan kemungkinan solusi alternatif $100 \%$ belum mampu, menerima atau menolak argumen disertai alasan yang jelas dan logis $90 \%$ belum mampu. Keterampilan berpikir kritis yang rendah juga didukung data hasil pretest pada uji coba 1 terhadap 11 siswa, pada pretest tersebut menunjukkan bahwa seluruh siswa memiliki keterampilan berpikir kritis pada kategori tidak terampil.

Siswa memerlukan bekal kemampuan untuk survive dan sukses dalam menjalani hidup di masyarakat yang penuh dengan tantangan, bukan hanya 
membekali dengan aspek materi saja karena kehidupan saat ini lebih dinamis oleh perkembangan Ilmu Pengetahuan dan Teknologi (IPTEK). Siswa dapat mengatasi tantangan tersebut apabila memiliki keterampilan berpikikir kritis (critical thinking). Siswa mampu menggunakan keterampilan berpikir kritis untuk menganalisis sesuatu yang berguna atau tidak berguna bagi dirinya, keluarga, masyarakat dan bangsanya di masa depan.

\section{METODE PENELITIAN}

Penelitian ini merupakan penelitian pengembangan karena mengembangkan perangkat pembelajaran fisika dengan pendekatan saintifik untuk meningkatkan hasil belajar dan melatihkan keterampilan berpikir kritis siswa SMA. Perangkat pembelajaran yang dikembangkan adalah Rencana Pelaksanaan Pembelajaran (RPP), Buku Siswa, Lembar Kerja Siswa (LKS), Lembar Penilaian Hasil Belajar, dan Penilaian Keterampilan Berpikir Kritis.
Dalam penelitian ini, rancangan perangkat pembelajaran di mulai dari mengidentifikasi masalah pembelajaran (instruction problems), menganalisis karakteristik siswa (learner characteristics), menganalisis tugas, mengidentifikasi tujuan pembelajaran, pengurutan materi/konten, mengidentifikasi strategi pembelajaran, desain cara menyampaikan informasi, mengembangkan perangkat pembelajaran dan membuat instrumen evaluasi. Menurut Morrison, Ross, Kalman, \& Kemp (2011), pengembangan perangkat pembelajaran merupakan suatu lingkaran yang kontinu. Dipilihnya model ini karena setiap tahap yang diikuti lebih sistematis, memberikan acuan yang cukup jelas dalam mendesain perangkat pembelajaran, tiap-tiap langkah pengembangan berhubungan langsung dengan aktivitas revisi, dan setiap pengembang (designer) bisa memulai dari langkah yang berbeda sesuai kebutuhan. Tahapan pengembangan perangkat pembelajaran dapat dilihat pada Gambar 1.

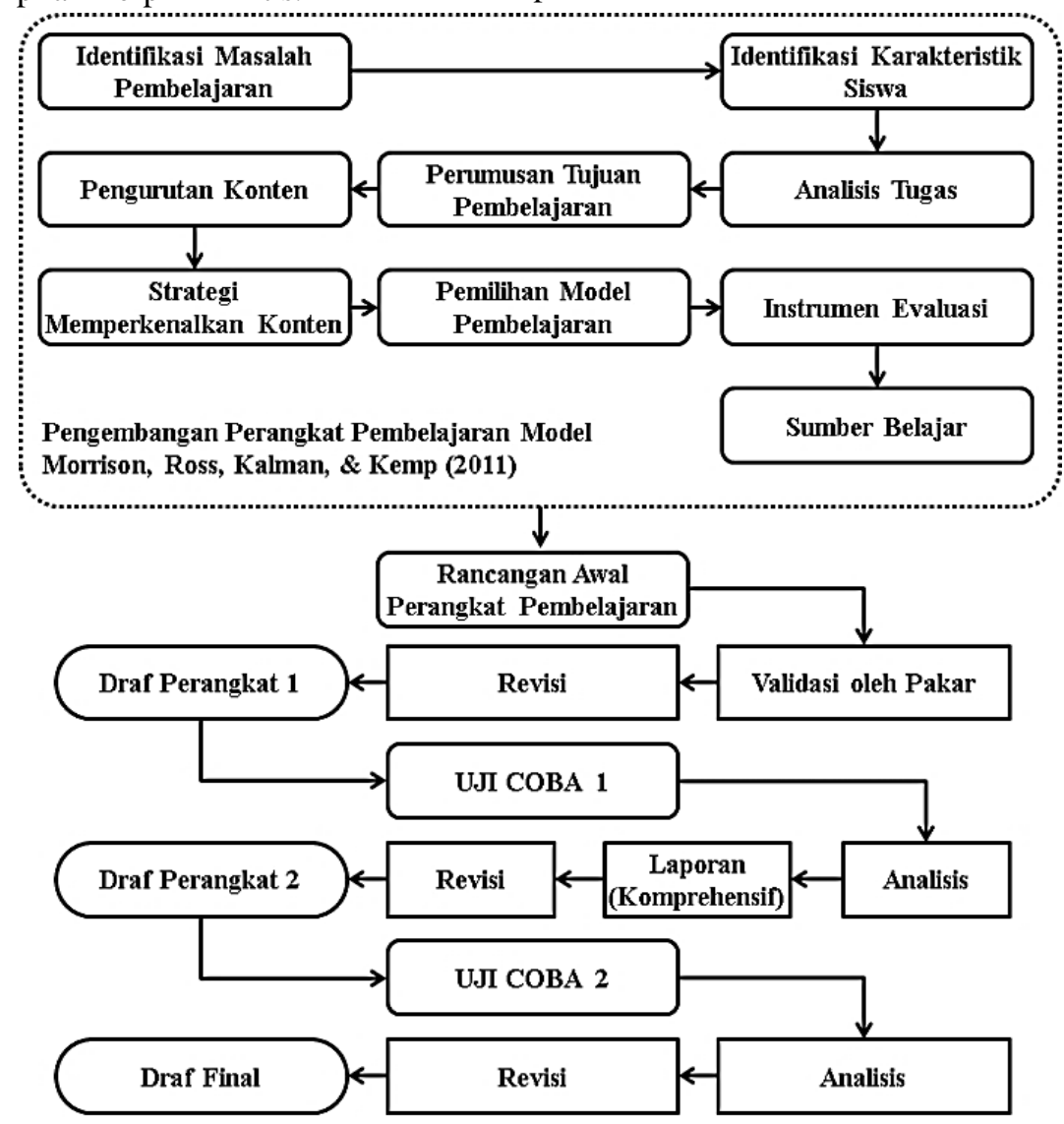

Gambar 1. Diagram Alir dari Tahapan Pengembangan Perangkat Pembelajaran

Dalam penelitian ini, perangkat akan melalui uji 1 pada sampel kecil dan uji 2 pada sampel besar dengan replikasi tiga kali/kelas. Desain uji coba perangkat menggunakan rancangan eksperimen Pre and Post Design, yang dapat digambarkan sebagai berikut :

$$
\text { A } \quad \text { - B - A }
$$

(Prunckun, 2010)
Keterangan:

A : Uji awal (pretes) untuk mengetahui penguasaan siswa terhadap materi pelajaran sebelum pembelajaran dilaksanakan. (Measurements are taken before the intervention)

B : Pelaksanaan pembelajaran dengan pendekatan saintifik. (baseline data) 
A : Uji akhir (posttes) untuk mengetahui penguasaan siswa terhadap materi pelajaran setelah pembelajaran dilaksanakan. (Measurements are taken after the intervention)

Teknik pengumpulan data digunakan untuk memperoleh bahan-bahan yang relevan, akurat, dan dapat digunakan dengan tepat sesuai tujuan penelitian. Teknik pengumpulan data yang digunakan dalam penelitian ini melalui observasi, pemberian tes, dan penyebaran angket.

Analisis hasil pengembangan perangkat pembelajaran dan hasil ujicoba perangkat pembelajaran fisika yang menggunakan model pembelajaran inkuiri terbimbing dalam penelitian ini adalah sebagai berikut.

\section{A. Analisis Kualitas Perangkat Pembelajaran}

Perangkat pembelajaran (RPP, Buku Siswa, LKS dan Penilaian Hasil Belajar) ditelaah oleh validator untuk memberikan penilaian terhadap kelayakan penggunaannya. RPP, Buku Siswa dan LKS ditelaah dengan Instrumen yang telah dikembangkan. Untuk Lembar Penilaian Hasil Belajar yang dikembangkan dilakukan validasi isi, bahasa dan penulisan soal sesuai dengan Instrumen. Data hasil validasi dianalisis secara deskriptif kualitatif. Dalam penelitian ini Passing Grade (batas penerimaan) adalah skor rerata $(\bar{X})$ dari hasil penilaian para validator dan kemudian dicocokkan dengan kriteria penilaian perangkat hasil pembelajaran. Adapun kriteria penilaian perangkat hasil pembelajaran dapat dilihat pada Tabel 1 berikut.

Tabel 1. Kriteria Pengkategorian Penilaian RPP, Buku Siswa dan LKS

\begin{tabular}{|c|c|}
\hline Interval Skor & Kategori Penilaian \\
\hline $\bar{X}>3,50$ & Sangat Layak \\
\hline $3,00<\bar{X} \leq 3,49$ & Layak \\
\hline $2,00<\bar{X} \leq 2,99$ & Sedang \\
\hline $1,00<\bar{X} \leq 1,99$ & Kurang \\
\hline $\bar{X} \leq 1,00$ & Rendah \\
\hline
\end{tabular}

\section{B. Analisis Tingkat Keterbacaan Buku Siswa dan LKS}

Tingkat keterbacaan merupakan ukuran menarik atau tidaknya isi dan penampilan serta pemahaman siswa terhadap Buku Siswa dan LKS. Teknik analisis dilakukan secara deskriptif kuantitatif persentase. Siswa diminta memberikan pendapatnya mengenai keterbacaan Buku Siswa dan LKS dengan mengisi Instrumen.

\section{Analisis Keterlaksanaan RPP}

Pengamatan keterlaksanaan RPP dilakukan oleh dua pengamat yang sudah dilatih memberikan penilaian yang tepat pada Instrumen. Kriteria setiap fase pembelajaran yang dinilai dengan memberikan cheklis pada kolom keterlaksanaan (ya atau tidak) dan pada kolom penilaian (4:sangat baik, 3:baik, 2:cukup baik, 1: kurang baik). Data yang diperoleh selanjutnya dianalisis secara deskriptif kuantitatif dengan teknik persentase dengan rumus:

$$
P=\frac{\sum K}{\sum N} \times 100 \%
$$

Keterangan:

$\mathrm{P}=$ Persentase keterlaksanaan RPP

$\sum K=$ Jumlah aspek yang terlaksana

$\sum N=$ Jumlah keseluruhan aspek yang diamati

Persentase keterlaksanaan RPP menggunakan kriteria seperti yang tercantum pada Tabel 2 sebagai berikut.

Tabel 2. Kriteria Pengkategorian Keterlaksanaan RPP

\begin{tabular}{|c|c|c|}
\hline No & Persentase & Keterangan \\
\hline 1 & $0,0 \%-24 \%$ & Tidak terlaksana \\
\hline 2 & $25 \%-49 \%$ & Kurang terlaksana \\
\hline 3 & $50 \%-74 \%$ & Terlaksana baik \\
\hline 4 & $75 \%-100 \%$ & $\begin{array}{c}\text { Terlaksana sangat } \\
\text { baik }\end{array}$ \\
\hline
\end{tabular}

Penilaian keterlaksanaan RPP pada setiap langkah ditentukan dengan membandingkan rata-rata skala penilaian yang diberikan kedua pengamat dengan kriteria penilaian sebagai berikut.

Tabel 3. Kriteria Penilaian Keterlaksanaan RPP Pada Setiap Langkah

\begin{tabular}{|c|c|c|}
\hline No & $\begin{array}{c}\text { Rerata Penilaian } \\
\text { Keterlaksanaan }\end{array}$ & Keterangan \\
\hline 1 & $1,00-1,49$ & Kurang baik \\
\hline 2 & $1,50-2,49$ & Cukup baik \\
\hline 3 & $2,50-3,49$ & Baik \\
\hline 4 & $3,50-4,00$ & Sangat baik \\
\hline
\end{tabular}

\section{Analisis Aktivitas Siswa}

Aktivitas siswa diukur oleh dua pengamat dengan menggunakan Instrumen. Data yang diperoleh selanjutnya dianalisis deskriptif kuantitatif dengan menggunakan rumus Percentage of Agreement, yaitu :

$$
P=\frac{\sum R}{\sum N} \times 100 \%
$$

Keterangan:

$\mathrm{P} \quad=$ Persentase keterlaksanaan RPP

$\sum R=$ Jumlah frekuensi tiap aktivitas yang muncul

$\sum N=$ Jumlah keseluruhan frekuensi aktivitas

\section{E. Analisis Hasil Belajar Siswa}

Berdasarkan data hasil posttest dianalisis secara deskriptif kualitatif tentang hasil belajar siswa yang 
meliputi hasil belajar sikap, pengetahuan, dan keterampilan.

1. Hasil Belajar Pengetahuan dan Keterampilan

Berdasarkan hasil posttest, hasil belajar pengetahuan dan keterampilan ditentukan ketuntasannya yaitu ketuntasan individual dan klasikal. Secara individual siswa dikatakan tuntas apabila ratarata ketercapaian indikator yang diwakili tujuan pembelajaran memenuhi Kriteria Ketuntasan Minimum (KKM) mata pelajaran fisika di SMA Negeri 1 Batu Sopang yaitu 70, dengan perhitungan sebagai berikut:

Ketuntasan Individual $=\frac{\sum \text { Indikator yang Tuntas }}{\sum \text { Jumlah indikator }} \times 100 \%$

Ketuntasan hasil belajar secara klasikal dihitung dengan menggunakan rumus :

$$
\text { Ketuntasan Klasikal }=\frac{\sum \text { Siswa yang Tuntas }}{\sum \text { Siswa }} \times 100 \%
$$

Pembelajaran secara klasikal dikatakan tuntas apabila $\geq$ $80 \%$ individu tuntas.

\section{Hasil Belajar Sikap}

Nilai yang diberikan oleh dua orang pengamat ditentukan rata-rata, kemudian hasil yang diperoleh dicocokan dengan kriteria penilaian sikap pada Tabel 4 berikut.

Tabel 4. Kriteria Penilaian Sikap

\begin{tabular}{|c|c|c|}
\hline No. & Rentang Nilai & Keterangan \\
\hline 1. & $80-100$ & Sangat Baik \\
\hline 2. & $70-79$ & Baik \\
\hline 3. & $60-69$ & Cukup \\
\hline 4. & $<60$ & Kurang \\
\hline
\end{tabular}

(Diadaptasi dari Morrison, Ross, Kalman, \& Kemp, 2011)

Ketuntasan individual siswa dikatakan tuntas jika memperoleh nilai setidaknya menunjukkan sedang. Ketuntasan klasikal tercapai jika $80 \%$ siswa tuntas.

\section{Normalized Gain}

Analisis data hasil belajar siswa pada saat pretes dan postest dihitung dengan menggunakan normalized gain sebagai berikut :

$$
<\mathrm{g}>=\frac{\text { \%post test }-\% \text { pre test }}{100-\% \text { pre test }}
$$

$$
\begin{aligned}
& \text { Kategori normalized gain }\langle g\rangle \text { : } \\
& \text { Tinggi }:(<g>) \geq 0.7 \\
& \text { Sedang }: 0.7>(<g>)>0.3 \\
& \text { Rendah }:(<g>) \leq 0.3
\end{aligned}
$$

(Hake, 1999)
4. Sensitivitas Soal

Indeks sensitivitas dari butir soal merupakan ukuran seberapa baik soal membedakan antara siswa yang telah menerima pembelajaran dengan siswa yang belum menerima pembelajaran. Indeks sensitivitas mempunyai rentang antara 0 sampai 1 . Untuk menghitung sensitivitas soal digunakan rumus sebagai berikut.

Sensitivitas Soal $=\frac{R_{a}-R_{b}}{T}$

Keterangan:

$\mathrm{Ra}=$ Banyaknya siswa yang menjawab benar pada tes akhir

$\mathrm{Rb}=$ Banyaknya siswa yang menjawab benar pada tes awal

$\mathrm{T}=$ Banyaknya siswa yang mengikuti tes

Indeks sensitivitas antara 0.00 sampai 1.00, butir soal dikatakan peka terhadap efek-efek pembelajaran apabila sensitivitas soal lebih besar atau sama dengan 0,40. (Gronlund, 1977).

\section{F. Analisis Keterampilan Berpikis Kritis}

Berdasarkan data hasil tes berpikir kritis dilakukan analisis secara deskriptif kualitatif dari perolehan skor siswa. Analisis keterampilan berpikir kritis siswa dilakukan dengan memberikan skor siswa dalam menjawab soal tes berbentuk essay. Pemberian skor berdasarkan skala berpikir kritis menurut Ennis, yaitu tidak terampil (1), kurang terampil (2), terampil (3) dan sangat terampil (4). Hasil belajar keterampilan berpikir kritis siswa pada saat pretes dan postest dianalisis dengan menggunakan normalized gain untuk melihat perkembangan keterampilan berpikir kritis siswa.

\section{G. Analisis Respon Siswa}

Angket respon siswa (Instrumen 8 halaman 239) digunakan untuk mengetahui pendapat siswa terhadap perangkat pembelajaran dengan pendekatan saintifik yang dikembangkan, suasana belajar dan cara guru mengajar. Respon siswa dianalisis secara deskriptif kuantitatif dengan menggunakan persentase, yaitu jumlah respon yang siswa berikan dibagi jumlah keseluruhan siswa, kemudian dikalikan 100\%. Rumus perhitungan respon siswa adalah sebagai berikut:

Keterangan:

$$
P=\frac{\sum R}{\sum N} \times 100 \%
$$

$$
\begin{aligned}
& \mathrm{P}=\text { Persentase respon siswa } \\
& \sum R=\text { Jumlah respon yang siswa berikan } \\
& \sum N=\text { Jumlah keseluruhan siswa }
\end{aligned}
$$

\section{H. Analis Kendala Selama Pembelajaran}

Temuan kendala-kendala selama pembelajaran dianalisis secara deskriptif kualitatif melalui diskusi 
antara pengamat dan peneliti. Hasil diskusi kemudian dicari solusi alternatifnya untuk mengatasi kendala yang muncul baik sebelum maupun selama proses belajar mengajar.

\section{HASIL PENELITIAN DAN DISKUSI}

Hasil pengembangan perangkat pembelajaran fisika menggunakan pendekatan saintifik untuk meningkatkan hasil belajar dan melatihkan keterampilan berpikir kritis yang dikembangkan telah valid untuk digunakan dalam pembelajaran. RPP yang dikembangkan mengikuti alur dari pembelajaran dengan pendekatan saintifik, meliputi: (1) Mengamati; (2) Menanya; (3) Mengumpulkan informasi atau eksperimen; (4) Mengasosiasikan atau mengolah informasi; dan 5) Mengkomunikasikan informasi atau menyampaikan hasil. Hasil validasi RPP oleh validator dapat dilihat pada Gambar 2. berikut.

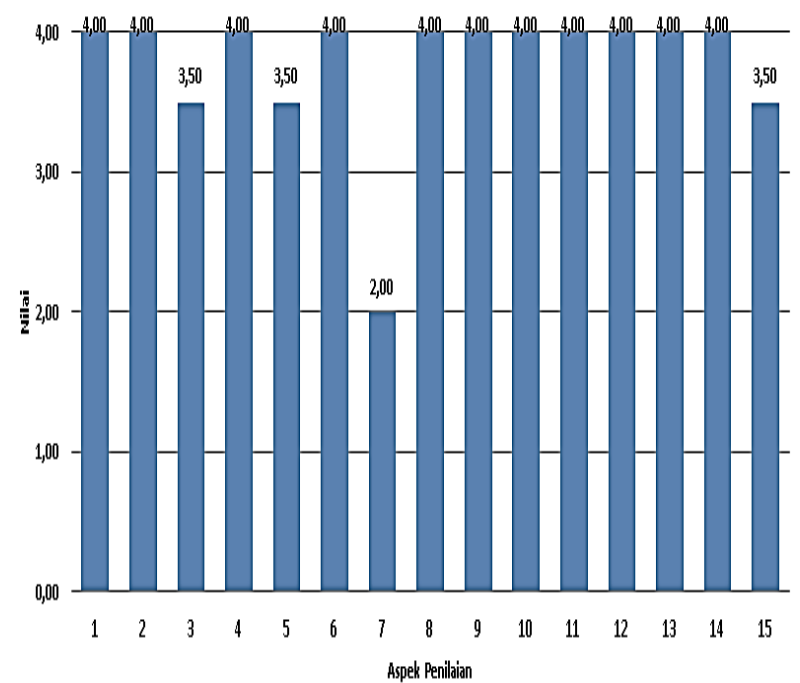

Gambar 2. Hasil Validasi RPP

Keterangan aspek penilaian:

1. Kompetensi inti

2. Kompetensi dasar

3. Indikator

4. Tujuan pembelajaran

5. Kesesuaian tujuan dengan indicator

6. Memfokuskan siswa, apersepsi, tujuan

7. Memberikan masalah

8. Merumuskan masalah

9. Merumuskan hipotesis

10. Mengumpulkan data

11. Menarik kesimpulan

12. Skenario indikator dalam pembelajaran

13. Penggunaan buku siswa dan LKS

14. LKS menunjang tujuan

15. Langkah pendekatan saintifik

Hasil validasi LKS oleh validator dapat dilihat pada Gambar 3. berikut.

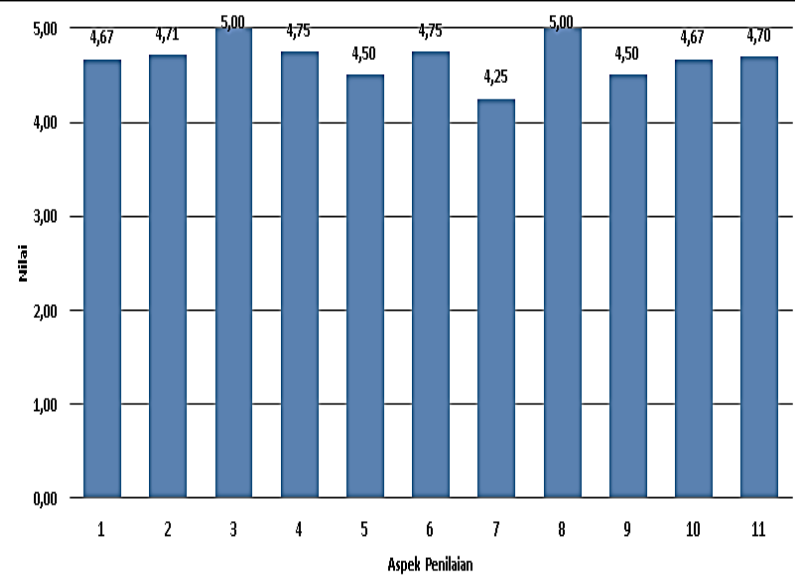

Gambar 3. Hasil Validasi LKS

Keterangan aspek penilaian:

1. Petunjuk

2. Pendekatan penulisan

3. Kebenaran konsep fisika

4. Kedalaman konsep

5. Keluasan konsep

6. Kejalasan kalimat

7. Kebahasaan

8. Kegiatan siswa/percobaan fisika

9. Penampilan fisika

10. Kelayakan isi

11. Pertanyaan

Hasil validasi buku ajar siswa oleh validator dapat dilihat pada Gambar 4. berikut.

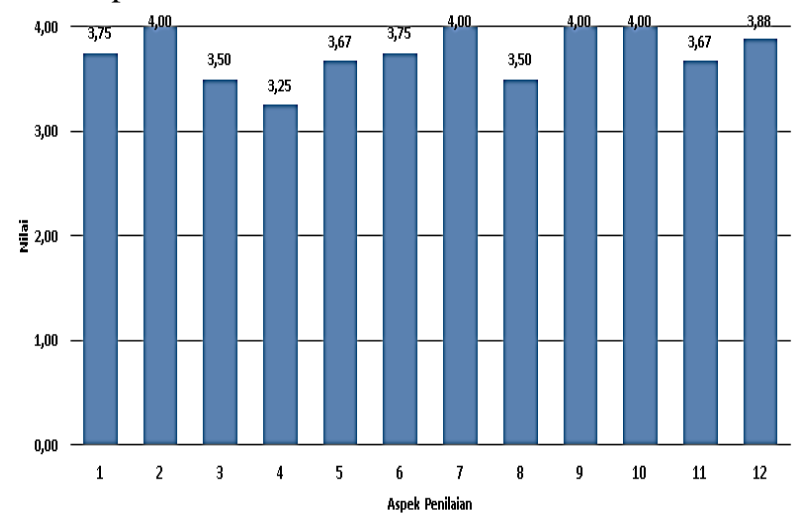

Gambar 4. Hasil Validasi Buku Ajar Siswa

Keterangan aspek penilaian:

1. Cakupan materi

2. Akurasi materi

3. Kemutakhiran

4. Memunculkan rasa ingin tahu

5. Membelajarkan berpikir kritis

6. Bahasa sesuai perkembangan siswa

7. Komunikatif

8. Dialogis dan interaktif

9. Lugas

10. Sesuai kaidah bahasa Indonesia

11. Teknik penyajian

12. Penyajian pembelajaran 
Hasil validasi instrumen hasil belajar siswa oleh validator dapat dilihat pada Gambar 5-8. berikut. 4,00

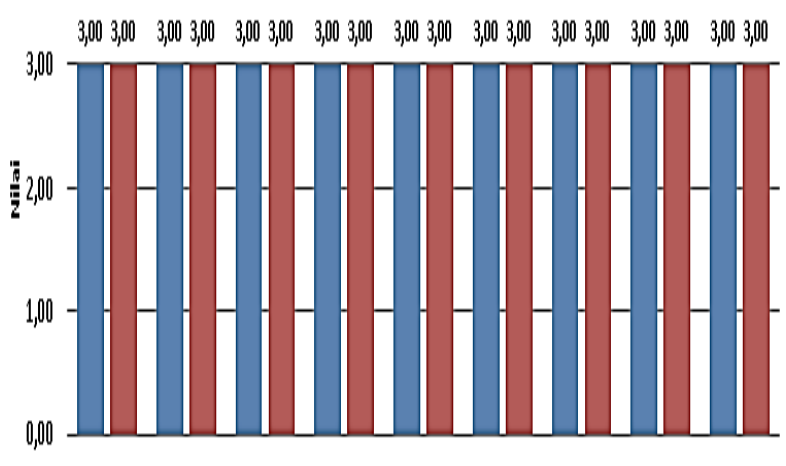

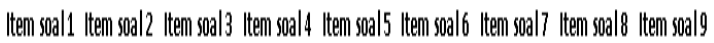

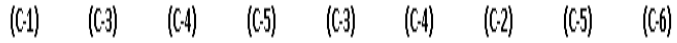

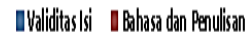

Gambar 5. Hasil Validasi Isntrumen Hasil Belajar Pengetahuan

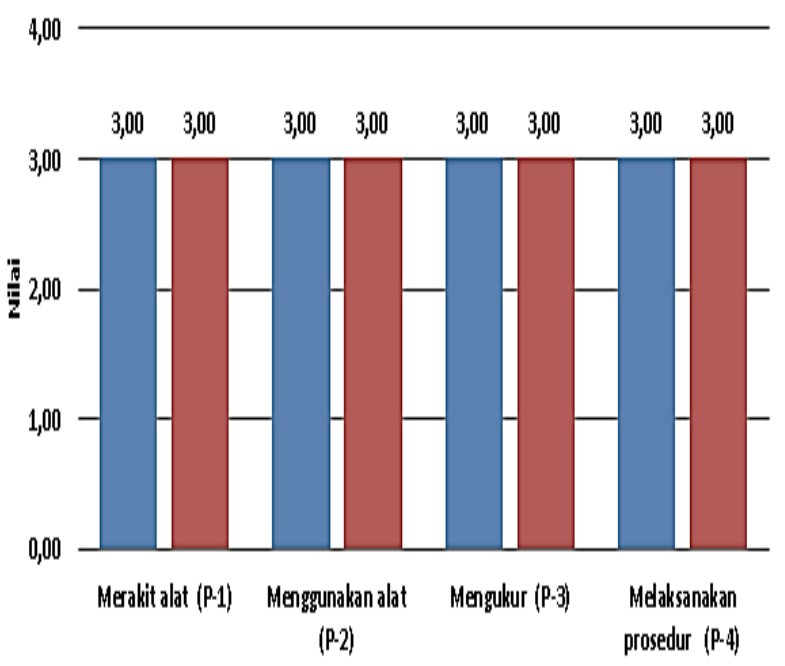

uValiditas lsi पBahass dan Penulisan

Gambar 6. Hasil Validasi Isntrumen Hasil Belajar Keterampilan

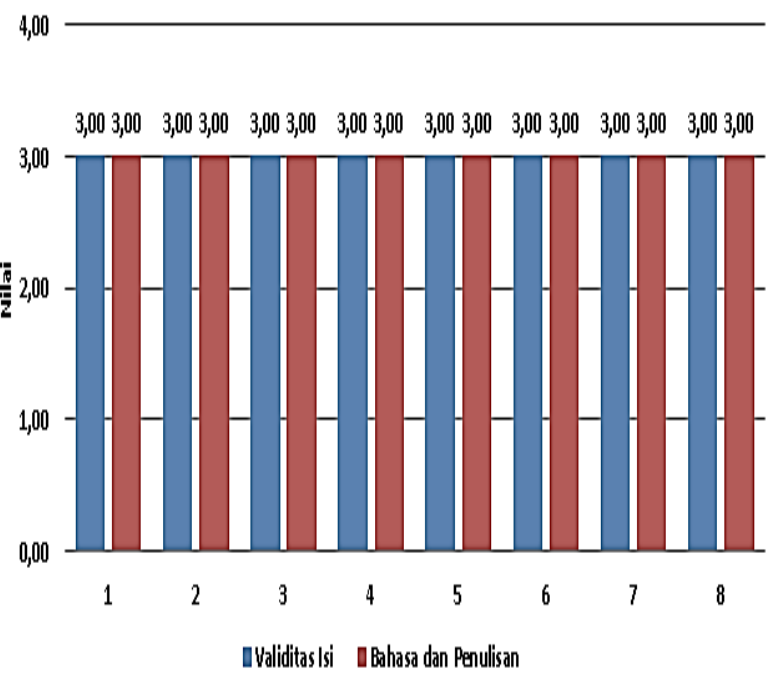

Gambar 7. Hasil Validasi Isntrumen Hasil Belajar Sikap
Keterangan aspek penilaian sikap:

1. Berdoa

2. Bersyukur

3. Hubungan baik dengan sesame

4. Menerima (receiving) (A-1)

5. Merespon (responding) (A-2)

6. Menilai (valuing) (A-3)

7. Mengorganisasikan (organizing) (A-4)

8. Mengkarakterisasikan (characterizing)(A-5)

4,00

$3,003,00 \quad 3,003,00 \quad 3,003,00 \quad 3,003,00 \quad 3,00 \quad 3,00 \quad 3,00 \quad 3,00 \quad 3,003,00 \quad 3,003,00$

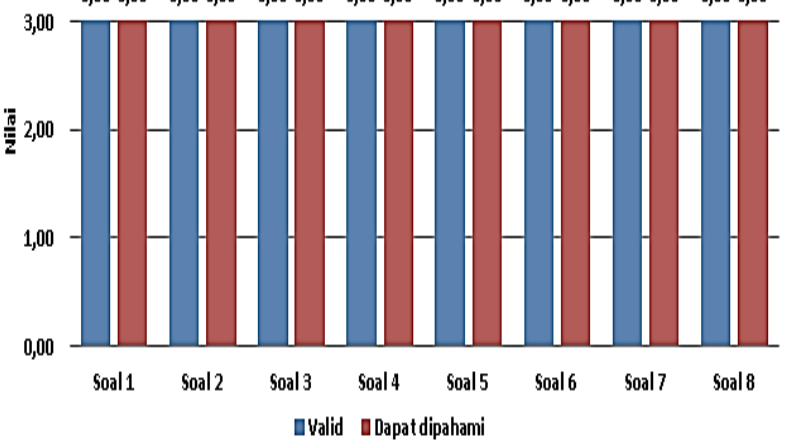

Gambar 8. Hasil Validasi Isntrumen Hasil Belajar Keterampilan Berpikir Kritis

Hasil pengamatan keterlaksanaan perangkat pembelajaran yang dikembangkan telah praktis untuk digunakan. Hasil pengamatan keterlaksanaan RPP yang dilakukan oleh dua orang guru mata pelajaran fisika disajikan pada Gambar 9-11.

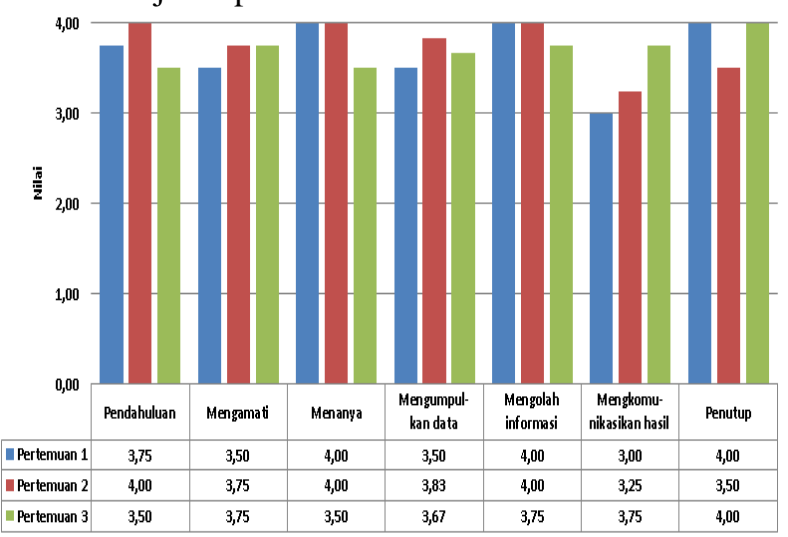

Gambar 9. Hasil Pengamatan Keterlaksanaan RPP di Kelas XI-IA-1

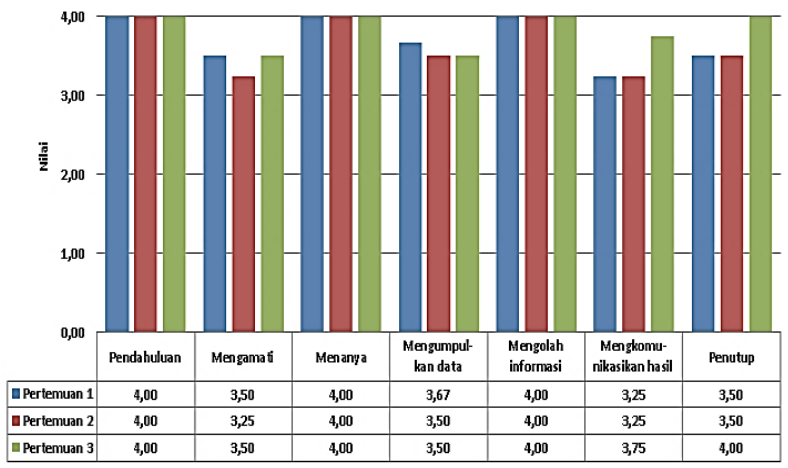

Gambar 10. Hasil Pengamatan Keterlaksanaan RPP di Kelas XI-IA-2 
Pada tahap pendahuluan, terdapat fase pendekatan saintifik mengamati yaitu guru menyampaikan apersepsi kepada siswa dan mengaitkan apersepsi tersebut dengan materi yang akan dipelajari. Apersepsi tersebut berupa alat penekan hidrolik dan gambar: dinding bendungan, tandon air pada ketinggian, pengangkat hidrolik, rem hidrolik, keramba terapung, dan kapal selam. Sesuai pendapat Morrison, Ross, Kalman, \& Kemp (2011) untuk mengajarkan faktafakta, maka siswa disajikan pengalaman terhadap benda-benda fakta tersebut. Jadi lebih konkritnya pada kegiatan apersepsi disajikan benda-benda nyata untuk diamati siswa, tetapi peneliti hanya bisa menyajikan benda/alat penekan hidrolik dan gambar benda-benda yang susah untuk dihadirkan dalam kelas.

Pada kegiatan fase pendekatan saintifik mengamati dan menanya, guru memfasilitasi siswa untuk melakukan pengamatan, melihat, membaca, dan mendengar, kemudian membimbing siswa untuk merumuskan pertanyaan/masalah dengan jelas. Hal tersebut sesuai dengan pendapat Chappell (2010) bahwa ilmuwan sering memiliki pertanyaan tentang banyak hal, ketika para ilmuwan memiliki pertanyaan mereka ingin menjawab dan menempuh proses untuk menemukan solusi. Para ilmuwan mulai dengan sebuah pertanyaan, kemudian mengumpulkan informasi penelitian tentang pertanyaan atau masalah tersebut. Pengamatan bisa dilakukan dengan membawa siswa ke dunia alam nyata, pengalaman kehidupan sehari-hari, atau membawa alam ke kelas bila memungkinkan, sehingga siswa bisa melihat, mendengar, dan menyentuh, bahkan apabila situasi mendukung keselamatan siswa bisa merasakan bau dan rasa (Koschmann, 2011).

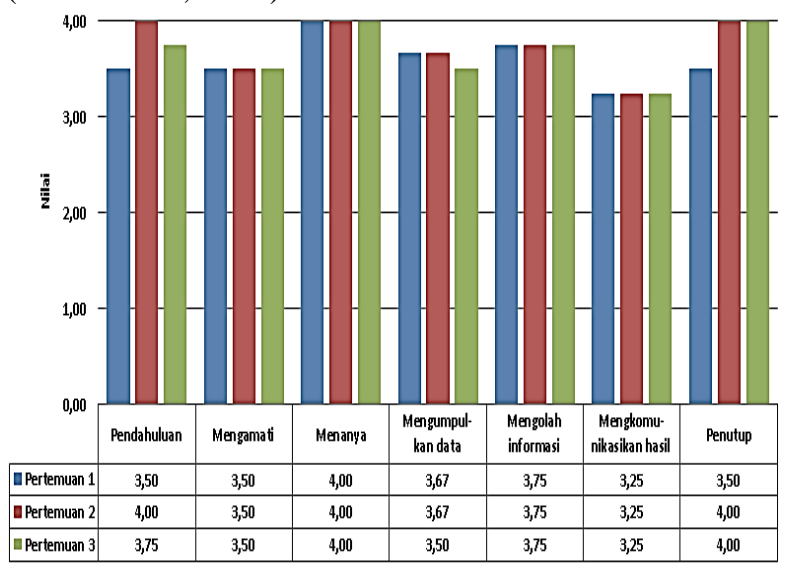

Gambar 11. Hasil Pengamatan Keterlaksanaan RPP di Kelas XI-IA-3

Pada kegiatan fase pendekatan saintifik mengumpulkan data, guru membimbing siswa untuk merumuskan hipotesis. Pada kegiatan ini, guru melaksanakan bimbingan yang lebih intensif karena siswa belum terbiasa dan untuk merumuskan hipotesis siswa harus mengetahui pengaruh antara variabel manipulasi dan variabel respon. Hal tersebut senada dengan pendapat Kothari (2004) bahwa hipotesis harus sangat spesifik dan terbatas pada penelitian karena akan diuji kebenarannya, peran hipotesis adalah untuk membimbing peneliti dalam pembatasan bidang penelitian dan untuk membuatnya tetap di jalur yang benar.

Pada kegiatan inti mengkomunikasikan hasil, siswa mempresentasikan hasil diskusi kelompok mereka secara bergantian di depan kelas. Menghargai bagaimana sains bekerja atau yang lebih penting meniru bagaimana para ilmuwan bekerja, siswa harus memperoleh pemahaman dan menajalani proses mengomunikasikan hasil pengetahuan kepada siswa lain, ilmuwan dan masyarakat (Williams, 2011). Presentasi tersebut dilaksanakan setiap kelompok secara bergantian, siswa kelompok yang lain berperan sebagai pendengar, pemberi argumen untuk mengevaluasi kembali kesimpulan yang dibuat jika terjadi perbedaan yang cukup mencolok, siswa juga memberikan solusi alternatif untuk menyelesaiakan masalah terutama jika terjadi perbedaan jawaban yang sangat mencolok.

Aktivitas siswa selama proses pembelajaran yang diamati oleh dua orang guru mata pelajaran fisika disajikan pada Gambar 12-14.

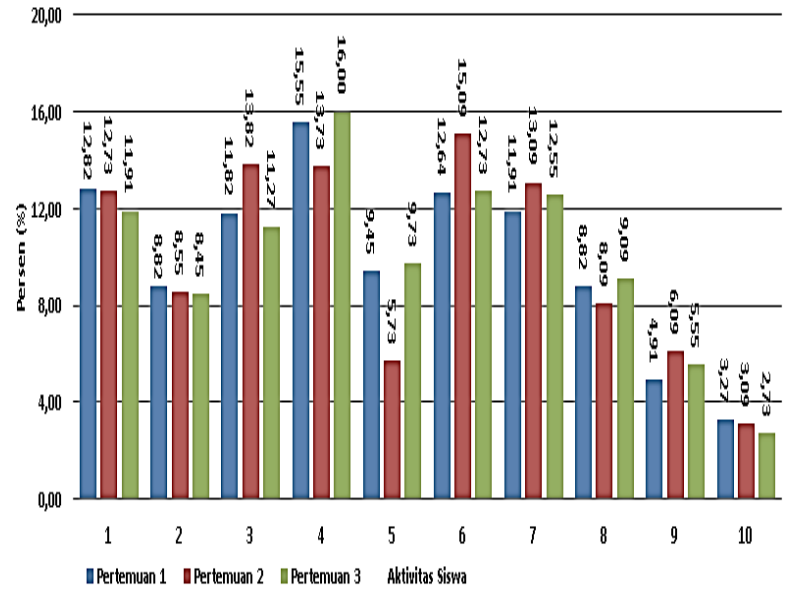

Gambar 12. Persentase Aktivitas Siswa Kelas XI-IA-1

Aspek aktivitas siswa:

Mengamati

1. Memperhatikan penjelasan guru atau teman. Menanya

2. Membuat pertanyaan pada guru atau teman.

Mengumpulkan data

3. Membaca (mencari informasi).

4. Melakukan pengamatan percobaan.

5. Mencatat hasil pengamatan percobaan.

Mengolah data

6. Mendiskusikan tugas.

7. Berkerjasama

8. Bertanggung jawab terhadap tugas kelompok.

Mengkomunikasikan hasil

9. Mengemukakan ide (menjawab pertanyaan). 10.Perilaku tidak relevan. 


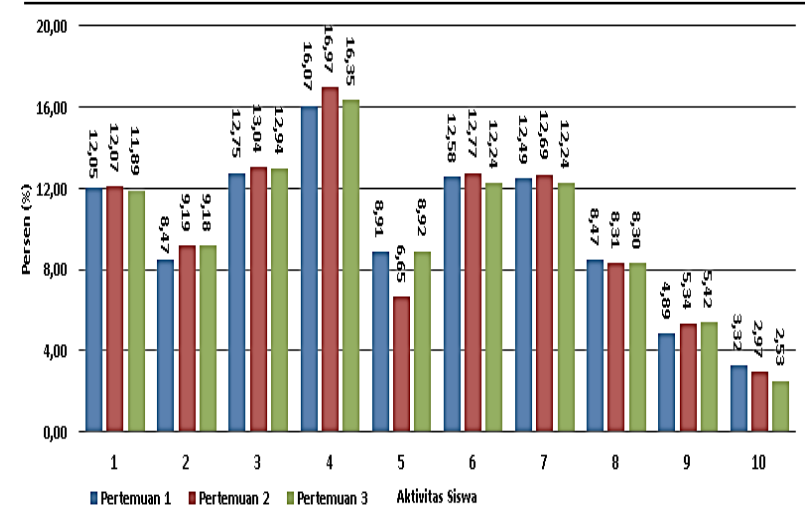

Gambar 13. Persentase Aktivitas Siswa Kelas XI-IA-2

Pembelajaran fisika dengan menerapkan pendekatan saintifik menempatkan guru sebagai fasilitator dan siswa sebagai subyek pembelajaran, hal tersebut tergambar dari aktivitas siswa yang dominan dalam mengikuti proses pembelajaran, antara lain: membaca, melakukan pengamatan, melaksanakan percobaan, mencatat hasil pengamatan, eksperimen, diskusi, mengemukakan ide, bertanya pada guru atau teman, bekerjasama, dan bertanggung jawab terhadap kelompok pada setiap pertemuan. Aktivitas siswa yang berhubungan dengan proses pembelajaran, yaitu membaca, memperhatikan penjelasan guru atau teman, melakukan pengamatan dari percobaan yang dilakukan atau diskusi, mengemukakan ide, bertanya, dan bertanggung jawab terhadap kelompok secara langsung meningkatkan kualitas belajar siswa menjadi deep learning (Light and Cox, 2009).

Pada setiap pertemuan terdapat aktivitas yang tidak relevan dengan persentase sekitar 1-3\%. Aktivitas yang tidak relevan ditandai dengan siswa yang bercerita di luar topik yang dipelajari, bermain, menggambar, atau mengerjakan hal lain di luar pembelajaran. Hal tersebut dapat direduksi dengan memberikan siswa kebebasan atau tanggung jawab yang cukup untuk melaksanakan tugas-tugas dan eksperimen serta menemukan sendiri hasil kerja mereka, tetapi guru juga harus memberikan penguatan positif ketika hasilnya benar dan penguatan negatif ketika hasilnya tidak benar (Jarvis, Holford, \& Griffin, 2004).

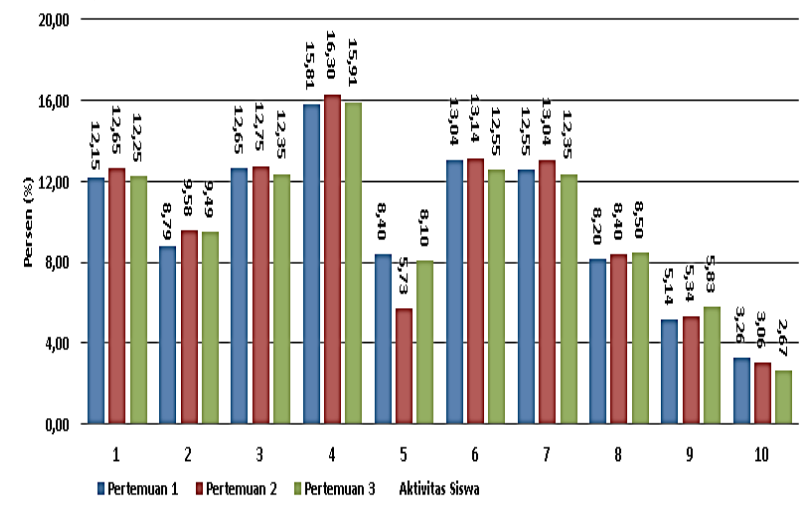

Gambar 14. Persentase Aktivitas Siswa Kelas XI-IA-3
Respon siswa setelah pembelajaran disajikan pada Gambar 15-20.

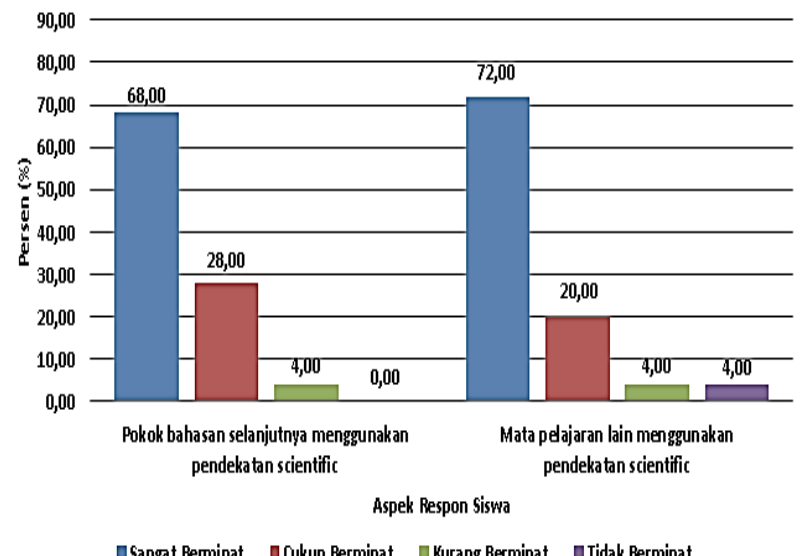

Gambar 15. Respon Siswa Kelas XI-IA-1 Terhadap Proses Pembelajaran

Sebagian besar siswa memberikan respon positif terhadap proses pembelajaran, hal tersebut berarti siswa tertarik apabila pembelajaran dengan pendekatan saintifikc diterapkan dalam pembelajaran fisika selanjutnya dan pada mata pelajaran selain fisika. Ketertarikan tersebut diharapkan dapat mendorong, menginspirasi, dan membiasakan siswa menggunakan pendekatan saintifik atau terbiasa menanggapi serta menyelesaikan masalah sehari-hari seperti yang ditempuh pada ilmuwan (scientist), hal tersebut sesuai dengan pendapat Flick \& Lederman (2006) bahwa penelitian ilmiah (scientific research) adalah ibarat game dengan dua players, yaitu ilmuwan yang bertanya dan alam/kehidupan yang memberikan jawaban.

Respon siswa terhadap komponen berpikir kritis didapatkan hasil bahwa sebagian besar siswa menyatakan cukup mudah mempelajari dan memahami keterampilan berpikir kritis. Respon positif siswa tersebut diharapkan dapat memberikan harapan perubahan penyelesaian masalah-masalah bangsa dengan cara-cara yang lebih bijaksana dan tidak anarkis karena siswa-siswa tersebut adalah generasi penerus bangsa, hal tersebut sesuai dengan pendapat Moore \& Parker (2012) bahwa keterampilan berpikir kritis adalah sebuah panduan untuk membuat keputusan yang bijaksana tentang apa yang harus dipikirkan dan dilakukan. Pada proses pembelajarannya, guru membimbing siswa secara klasikal dan memberikan kebebasan bagi siswa untuk mengemukakan pendapat sehingga memberikan kemudahan bagi siswa untuk menyelesaikan tugas yang diberikan. Hal ini berkesesuaian dengan respon sebagian besar siswa yang menyatakan bahwa penjelasan dan bimbingan yang diberikan guru pada saat menjelaskan, kerja kelompok, melaksanakan percobaan, membuat prakarya, eksperimen mudah dimengerti serta dipahami. 


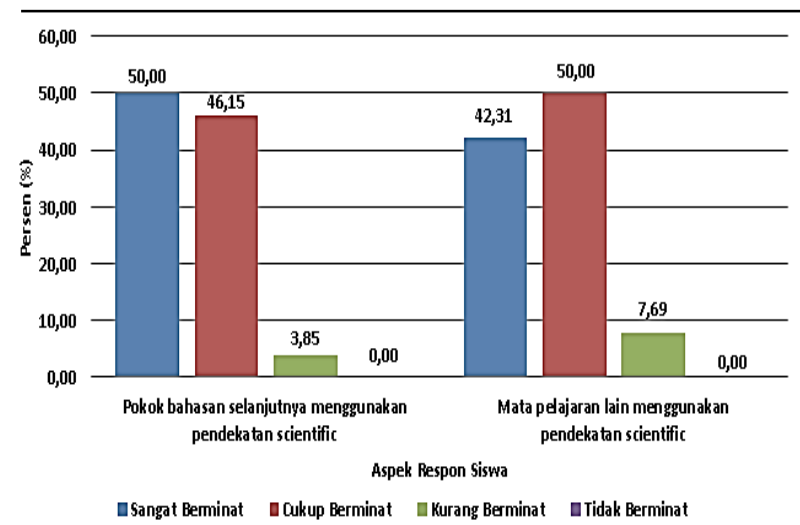

Gambar 16. Respon Siswa Kelas XI-IA-2 Terhadap Proses Pembelajaran

Pada indikator memberikan kemungkinan solusi alternatif untuk menyelesaikan masalah dan menerima atau menolak argumen, gagasan, atau keputusan disertai dengan alasan yang jelas dan logis, siswa memberikan penilaian kemudahan agak rendah karena indikator tersebut memang menantang dilakukan, hal tersebut sesuai dengan pendapat Browne \& Keeley (2012) bahwa alasan adalah penjelasan atau penalaran kenapa kita harus percaya pada suatu kesimpulan. Argumen terdiri dari kesimpulan dan alasan-alasan yang mendukung kesimpulan itu. Jadi siswa perlu menalar untuk percaya atau tidak terhadap kesimpulan, kemudian mengumpulkan informasiinformasi pendukung, selanjutnya memberikan argumen.

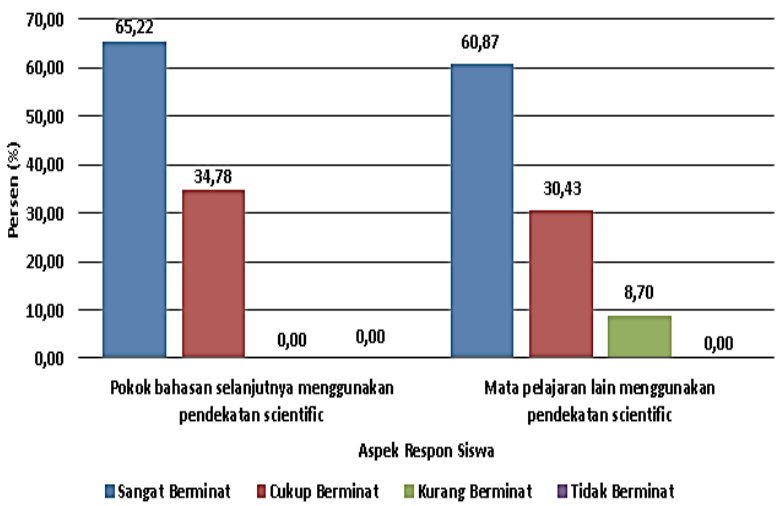

Gambar 17. Respon Siswa Kelas XI-IA-3 Terhadap Proses Pembelajaran

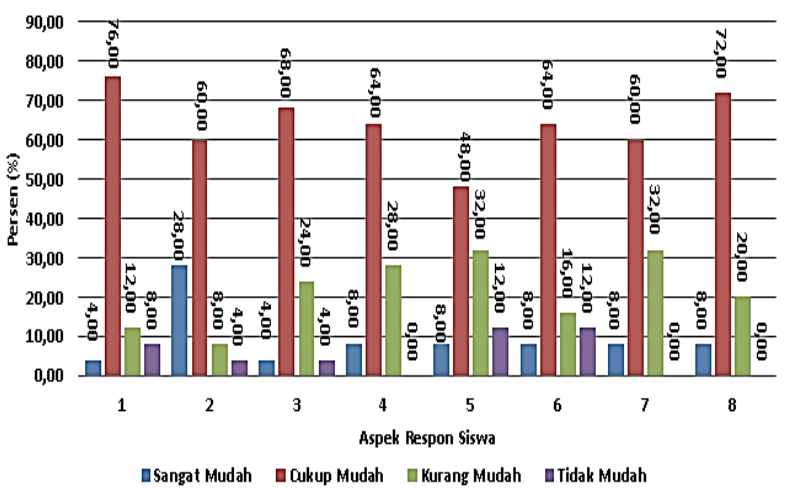

Gambar 18. Respon Siswa Kelas XI-IA-1 Terhadap Keterampilan Berpikir Kritis
Keteraqngan aspek berpikir kritis:

1. Merumuskan masalah dengan jelas dan dapat mengarahkan untuk menemukan jawaban.

2. Menganalisis kelemahan atau keterbatasan dalam pengumpulan data.

3. Merumuskan hipotesis berdasarkan pengetahuan yang dimiliki.

4. Menuliskan kesimpulan yang benar dan di dukung oleh data.

5. Mengevaluasi kesimpulan yang dibuat disertai alasan-alasan yang logis.

6. Mendefinisikan istilah yang digunakan dalam suatu wacana.

7. Memberikan kemungkinan solusi alternatif untuk menyelesaikan masalah.

8. Menerima atau menolak argumen, gagasan, atau keputusan disertai dengan alasan yang jelas dan logis.

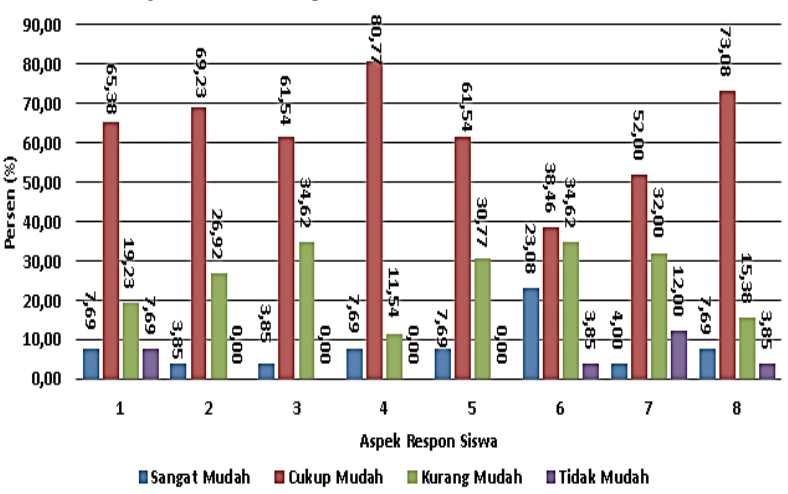

Gambar 19. Respon Siswa Kelas XI-IA-2 Terhadap Keterampilan Berpikir Kritis

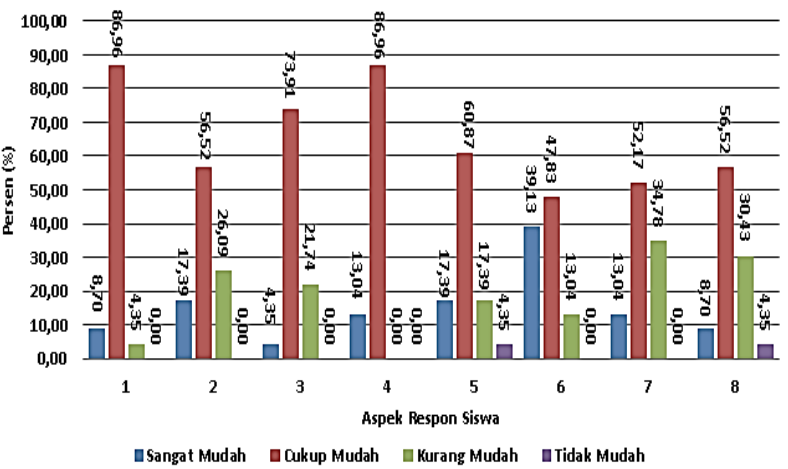

Gambar 20. Respon Siswa Kelas XI-IA-3 Terhadap Keterampilan Berpikir Kritis

Hasil implementasi perangkat pembelajaran yang dikembangkan telah efektif meningkatkan hasil belajar dan melatihkan keterampilan beprikir kritis siswa. Hasil belajar siswa disajikan pada Gambar 21-11.

Hasil belajar pengetahuan memiliki ketuntasan individual di atas $87 \%$. Hasil tersebut menunjukkan bahwa proses pembelajaran dengan menggunakan pendekatan saintifik berhasil membuat siswa mengingat, memahami, mengaplikasikan, menganalisis, mensintesis, dan mengevaluasi konsep, hukum dan teori yang dipelajari siswa pada proses pembelajaran. 
Pada kedua uji coba tersebut, semua indikator mengalami ketuntasan, terdapat tiga indikator (indikator 4, 8 dan 9) yang tuntas dengan persentase cukup/mepet, yaitu sekitar $73-77 \%$. Indikator 4 dan 8 adalah mensintesis dua persamaan dengan ranah pengetahuan C-5 dan indikator 9 adalah mengevaluasi dengan ranah pengetuan C-6. Pada perhitungan normalized gain, indikator-indikator tersebut menghasilkan gains score paling rendah yaitu sekitar 0,66-0,72. Hal tersebut terjadi karena ketiga indikator memiliki ranah pengetahuan yang tinggi, penemuan dalam pembelajaran siswa memerlukan bimbingan lebih dalam mensintesis atau menggabungkan dua persamaan dan mengevaluasi data soal untuk mengambil keputusan. Hal tersebut sesuai dengan pendapat Anderson \& Krattwohl (2001) bahwa proses kognitif yang paling banyak dijumpai dalam tujuan-tujuan di bidang pendidikan, yaitu mengingat, kemudian memahami dan mengaplikasikan, ke proses-proses kognitif yang jarang dijumpai, yakni menganalisis, mensintesis, dan mengevaluasi.

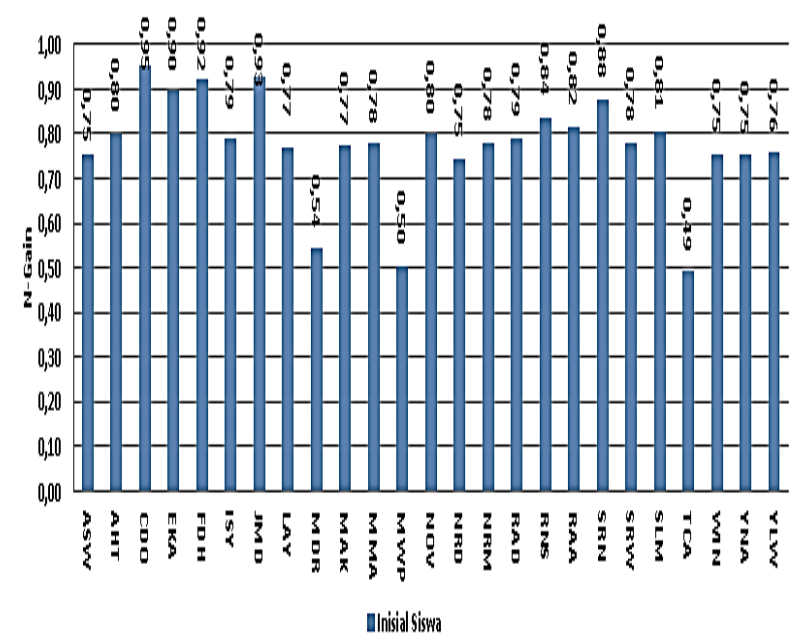

Gambar 21. Rangkuman Normalized Gain Hasil Belajar Pengetahuan Setiap Siswa Kelas XIIA-1

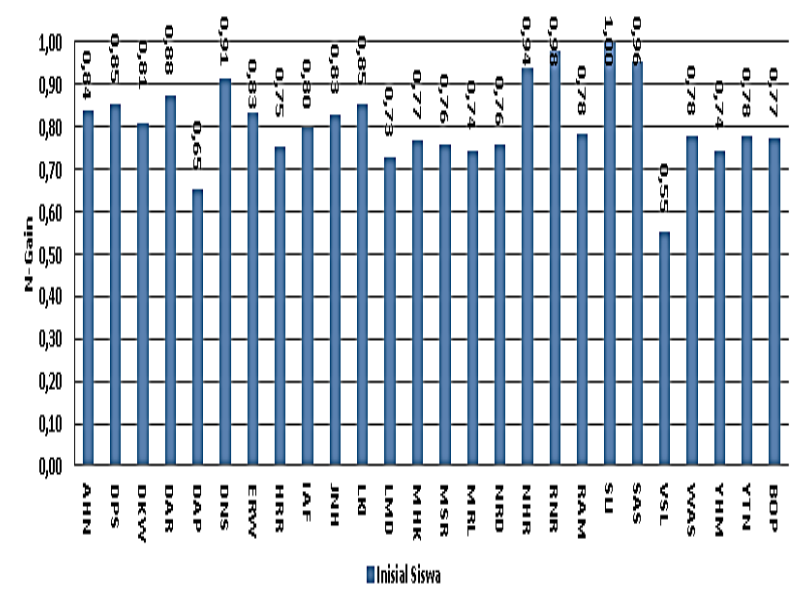

Gambar 22. Rangkuman Normalized Gain Hasil Belajar Pengetahuan Setiap Siswa Kelas XIIA-2

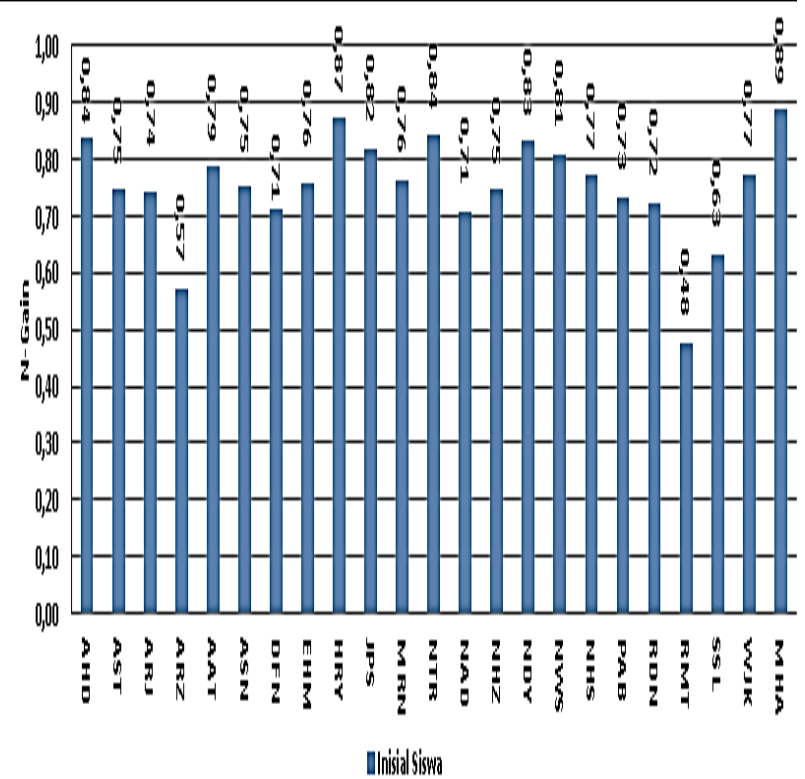

Gambar 23. Rangkuman Normalized Gain Hasil Belajar Pengetahuan Setiap Siswa Kelas XIIA-3

Hasil belajar keterampilan yang diamati dalam proses pembelajaran terdiri dari merakit, menggunakan alat, mengukur, melaksanakan prosedur percobaan/eksperi-men, dan membuat prakarya. Pada pertemuan pertama siswa melaksanakan percobaan menentukan massa jenis fluida yang memanfaatkan prinsip tekanan hidrostatis dan hukum utama hidrostatis, pada percobaan tersebut seluruh siswa mencapai ketuntasan yang berarti aspek-aspek yang dinilai terlaksana dengan baik. Pada pertemuan kedua, siswa membuat prakarya alat peraga hukum Pascal untuk mendukung informasi dan kemudahan dalam memahami hukum tersebut.

Pada pembuatan alat peraga tersebut seluruh siswa mencapai ketuntasan yang berarti aspek-aspek yang dinilai terlaksana dengan baik. Pada pertemuan ketiga, siswa melaksanakan eksperimen gaya ke atas/gaya apung (hukum Archimedes), pada eksperimen tersebut seluruh siswa berhasil mencapai ketuntasan yang berarti aspek-aspek yang dinilai terlaksana dengan baik. Definisi sederhana dari pembelajaran meliputi: (1) pembelajran membantu peserta didik untuk memperoleh pengetahuan dan keterampilan baru, (2) pembelajaran utama terdiri dari memberitahu, menunjukkan, membimbing siswa dalam tugas-tugas kinerja dan kemudian mengukur hasil (Singer, Murphy, \& Hines, 2003). Aktifitas pembelajaran dengan percobaan, membuat prakarya, dan eksperimen tersebut mengubah pandangan siswa terhadap fisika, fisika berguna bagi kehidupan, fisika menyenangkan, hal tersebut terlihat dari respon positif siswa jika pokok bahasan selanjutnya menggunakan pembelajaran dengan pendekatan saintifik. 


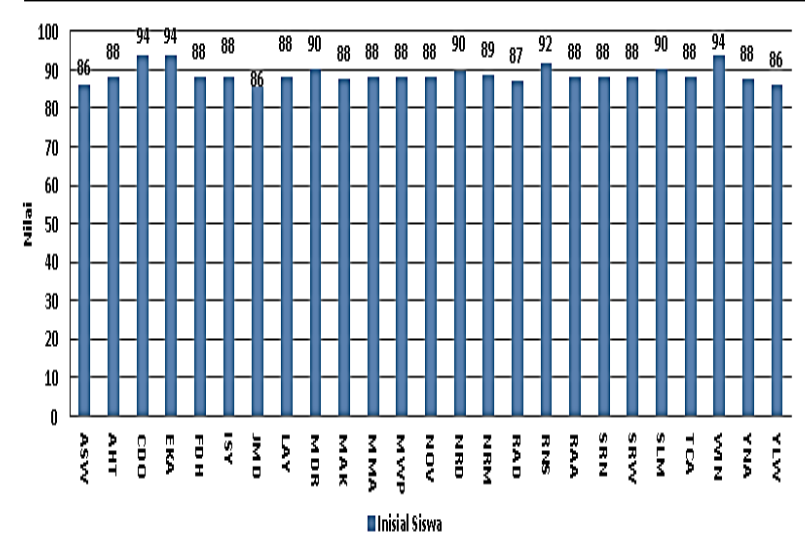

Gambar 24. Rerata Hasil Belajar Keterampilan Siswa Kelas XI-IA-1

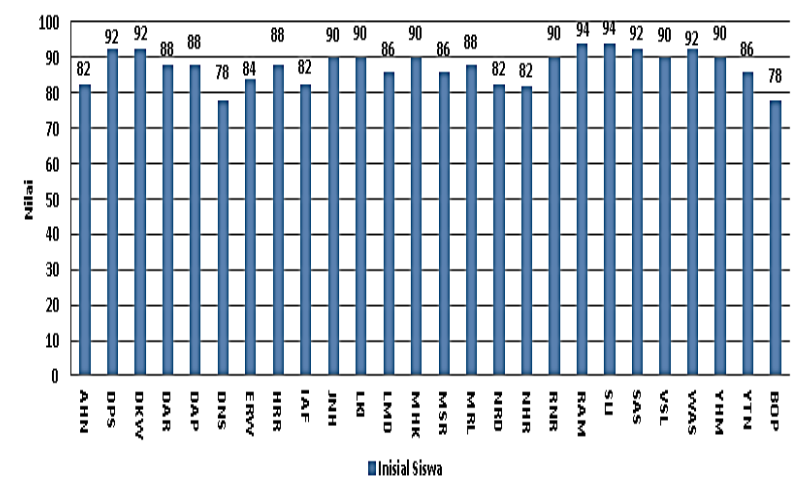

Gambar 25. Rerata Hasil Belajar Keterampilan Siswa Kelas XI-IA-2

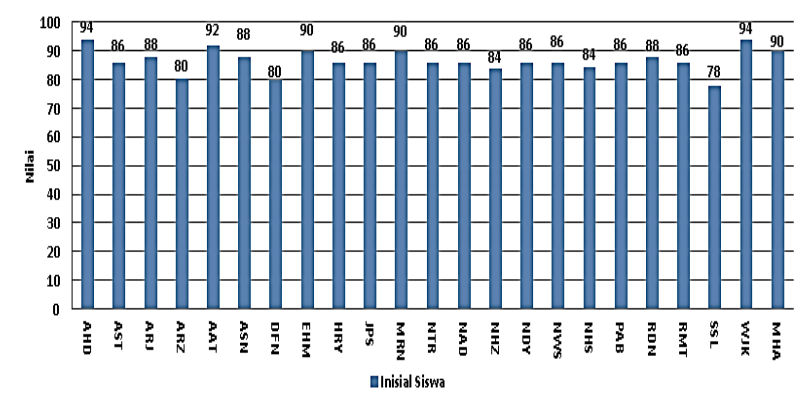

Gambar 26. Rerata Hasil Belajar Keterampilan Siswa Kelas XI-IA-3

Hasil belajar sikap yang diamati dalam proses pembelajaran terdiri dari dua, yaitu sikap spiritual dan sosial (Depdikbud, 2013). Sikap spiritual meliputi: berdoa, mengucapkan syukur, dan menjalin hubungan baik. Sikap sosial meliputi: menerima penjelasan, merespon pertanyaan, menilai pendapat, mengorganisasikan masalah, dan mengkarakterisasikan nilai (Morrison, Ross, Kalman, \& Kemp, 2011). Hasil belajar sikap spiritual dan sosial pada uji coba 1 dan 2 memiliki ketuntasan sebesar $100 \%$. Ketuntasan tersebut dapat terwujud karena indikatorindikator sikap dilatihkan dalam pembelajaran, sebagai contoh adalah mengucapkan syukur ketika berhasil mengerjakan aktifitas tertentu, sikap ini memang benarbenar dibiasakan dalam pembelajaran. Hal tersebut sesuai dengan pendapat Mulyasa (2013) pembentukan sikap atau karakter memang tidak bisa sim salabim atau terbentuk dalam waktu singkat, tapi indikator perilaku dapat dideteksi secara dini oleh guru. Pembelajaran menggunakan pendekatan saintifik juga mendukung pembiasaan nilai-nilai sikap tersebut, sebagai contoh adalah mengkarakterisasikan nilai sopan santun, yang dibiasakan pada saat siswa mempresentasikan hasil di depan kelas, misal mengucapkan salam pembuka dan penutup, bahasa yang digunakan tidak menyinggung perasaan, cara dan aturan menjawab dan menyanggah pendapat.

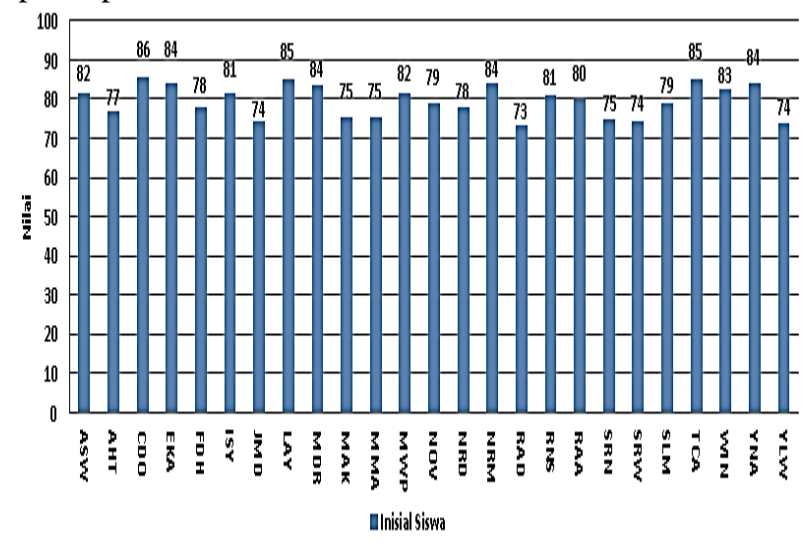

Gambar 27. Rerata Hasil Belajar Sikap Siswa Kelas XI-IA-1

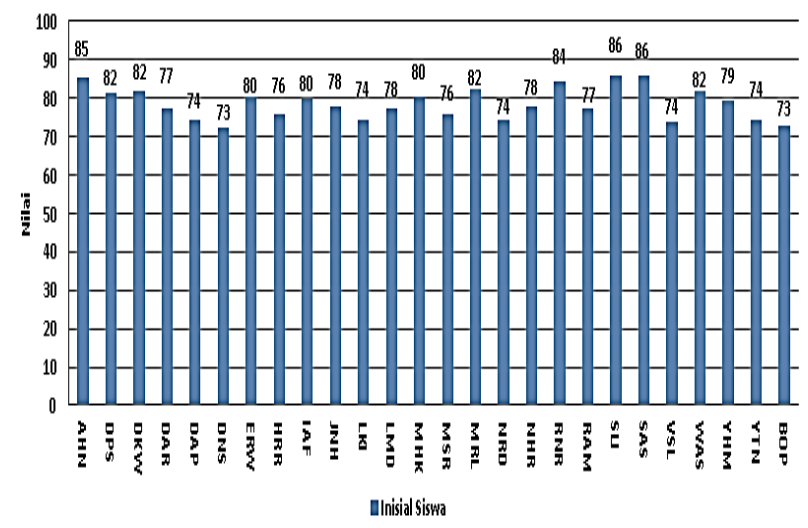

Gambar 28. Rerata Hasil Belajar Sikap Siswa Kelas XI-IA-2

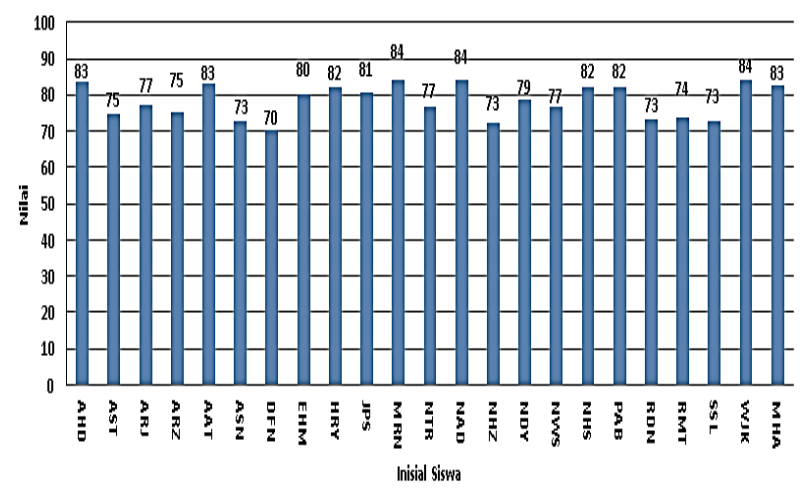

Gambar 29. Rerata Hasil Belajar Sikap Siswa Kelas XI-IA-3

Hasil belajar keterampilan berpikir kritis menunjukan bahwa semua siswa mengalami peningkatan kemampuan tersebut, peningkatan paling besar pada kategori tidak terampil menjadi terampil. Peningkatan tersebut terjadi karena dalam pembelajaran 
dengan menggunakan pendekatan saintifik memotivasi dan memfasilitasi siswa dalam melatih keterampilan berpikir kritis, sebagai contoh kemampuan membuat kesimpulan yang dilatihkan melalui fasilitas LKS, artinya siswa benar-benar dilatih untuk membuat kesimpulan dan dituliskan di LKS. Hal tersebut sesuai dengan pendapat Eggen \& Kauchak (2012) bahwa berpikir kritis adalah kemampuan dan kecenderungan untuk membuat dan melakukan asesmen terhadap kesimpulan yang didasarkan pada bukti, dan pendapat Moore \& Parker (2012) bahwa berpikir kritis bertujuan untuk memperbaiki kesimpulan, membuat pilihan, dan keputusan yang bijaksana.

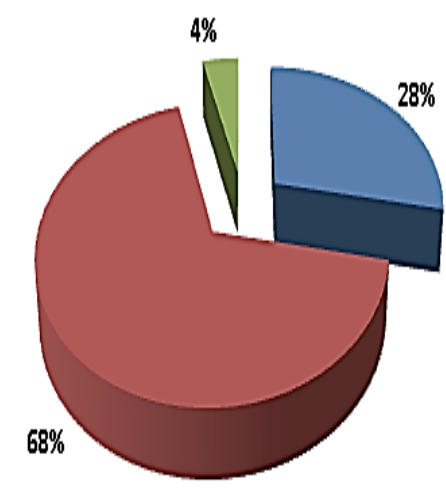

口Tidak Terampil · Kurang Terampil 口Tidak Terampil · Terampil uTidak Terampil · Sangat Terampil

Gambar 30. Persentase Perubahan Keterampilan Berpikir Kritis Siswa Kelas XI-IA-1

Berdasarkan data hasil belajar keterampilan berpikir kritis, siswa yang memiliki keterampilan ini dalam kategori terampil, maka hasil belajar pengetahuan dan sikapnya juga selaras atau mengikuti, artinya keterampilan berpikir kritis mendukung hasil belajar yang lain. Hal tersebut sesuai dengan pendapat Phan (2010) bahwa berpikir kritis adalah orientasi teoritis penting yang berfungsi membantu motivasi belajar siswa dalam proses belajar mengajar.

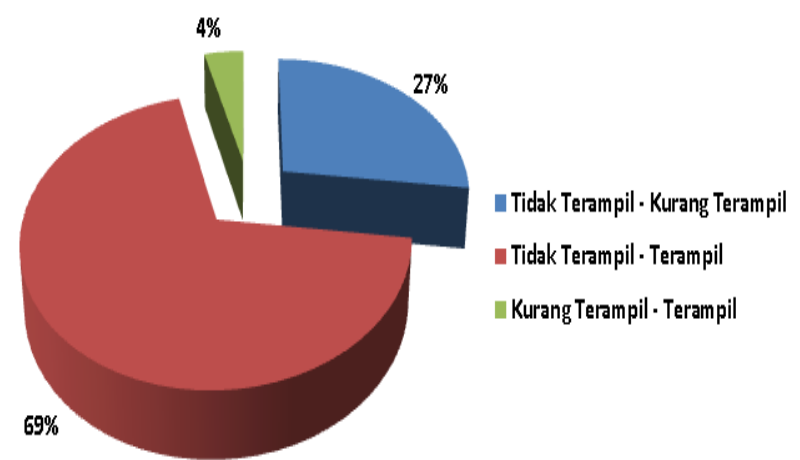

Gambar 31. Persentase Perubahan Keterampilan Berpikir Kritis Siswa Kelas XI-IA-2

Pendekatan saintifik memiliki langkah-langkah yang mengkondisikan dan cenderung menuntut guru memfasilitasi siswa untuk berpikir kritis, pendekatan tersebut juga memancing siswa untuk berpikir kritis. Dalam pendekatan saintifik terdapat langkah menanya, langkah ini sangat penting dalam memacu keterampilan berpikir kritis siswa, hal tersebut senada dengan pendapat Browne \& Keeley (2012) bahwa kemampuan berpikir kritis meliputi pengetahuan untuk membuat serangkaian pertanyaan kritis yang saling bertautan dan menjawab pertanyaan-pertanyaan tersebut pada saat yang tepat. Langkah yang lain adalah mengolah informasi/menalar, langkah ini juga penting dalam memacu keterampilan berpikir kritis siswa, hal tersebut juga senada dengan pendapat Browne \& Keeley (2012) bahwa nalar kritis yang lemah adalah penggunaan pemikiran kritis untuk mempertahankan keyakinan awal, nalar yang kuat adalah penggunaan pemikiran kritis untuk meninjau ulang semua klaim dan keyakinan, terutama miliki.

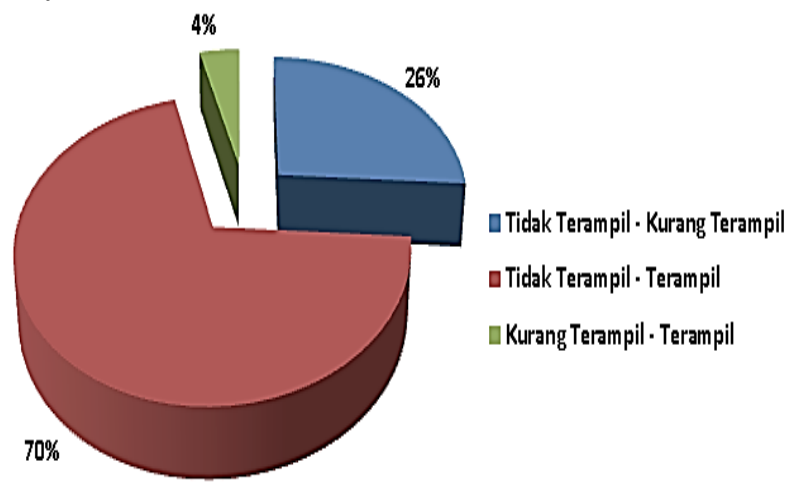

Gambar 32. Persentase Perubahan Keterampilan Berpikir Kritis Siswa Kelas XI-IA-3

\section{KESIMPULAN}

Berdasarkan hasil uji coba perangkat, analisis, diskusi, pembahasan, temuan-temuan dalam proses pembelajaran, maka secara umum dapat disimpulkan bahwa perangkat pembelajaran fisika dengan pendekatan saintifik yang dikembangkan telah valid, praktis, dan efektif untuk meningkatkan hasil belajar dan melatihkan keterampilan berpikir kritis siswa.

Saran dapat dikemukakan oleh peneliti berdasarkan penelititan yang telah dilakukan meliputi: 1) pada pendekatan saintifik kegiatan pengamatan, sebaiknya menyajikan produk teknologi yang nyata di kelas, minimal dengan gambar, video, miniatur atau bahkan produk asli jika memungkinkan, dengan demikian pembelajaran akan lebih bermakna, menantang dan masksimal sebagai informasi awal untuk siswa, 2) pada pendekatan saintifik kegiatan mengumpulkan data, dalam memberikan fasilitas kepada siswa memerlukan ide-ide kreatif. Fasilitas tersebut sangat diperlukan siswa dan dapat berupa: alam sekitar, buku siswa dibuat oleh guru, buku paket dari perpustakaan, artikel, majalah, koran, percobaan, prakarya, eksperimen, dan internet offline maupun online, 3) untuk menghilangkan aktivitas yang tidak relevan, guru sebaiknya menyiapkan dari awal, salah satu cara dengan menyajikan pengamatan dan fasilitas yang menarik, menantang, up to date (terbaru), lengkap tapi tidak harus mahal. 


\section{REFERENSI}

Akker, J. V., Bannan, B., Kelly, A. E., Nieveen, N., \& Plomp, T. (2013). Educational desgin research. Netherlands: Netherlands Institute for Curriculum Development (SLO).

Anderson, L. W., \& Krattwohl, D. R. (2010). Kerangka landasan untuk pembelajaran, pengajaran, dan asesmen. Yogyakarta: Pustaka Pelajar.

Arends, R. I. (2012). Learning to teach. New York: McGraw-Hill.

Bailin, S. (2002). "Critical thinking and science education". Science \& Education, No. 30, Vo. 11, 361-375.

Bloom, B. S., Englehart, M. D., Furst, E. J., Hill, W. H., \& Krathwohl, D. R. (1956). Taxonomy of educational objectives, the classification of educational goals, hanbook I: cognitive domain. New York: David McKay Company Inc.

Borich. (1994). Observation skills for effective teaching. United States of Amerika: Macmillan Publishing Company.

Browne, M. N., \& Keeley, S. M. (2012). Pemikiran kritis: panduan untuk mengajukan dan menjawab pertanyaan kritis. New Jersey: Indeks.

BSNP. (2014, Mei 28). Instrumen penilaian buku teks pelajaran tahun 2014. Dipetik Juni 26, 2014, dari Kelompok Peminatan MIPA: http://bsnpindonesia.org/id/?p=1340

Chappell, R. M. (2010). Solving science questions, a book abaout the scientific process. Florida: University of South Florida Press.

Depdikbud. (2013a). Permendikbud No. 81a Tentang Implementasi Kurikulum Pedoman Umum Pembelajaran. Jakarta: Depdikbud.

Depdikbud. (2013b). Kerangka dasar dan struktur kurikulum sekolah menengah atas/madrasah aliyah. Jakarta: Depdikbud.

Eggen, P., \& Kauchak, D. (2012). Strategi dan model pembelajaran: mengajarkan konten dan keterampilan berpikir. Boston: Indeks.

Ennis, R. H. (1996). Critical thinking. New Jeresy: Prentice-Hall.

Epstein, L. C. (1995). Thinking physics practical lessons in critical thinking. San Francisco: Insight Press.

Erceg, N., Aviani, I., \& Mesic, V. (2013). "Probing students' critical thinking processes by presenting ill-defined physics problems". Revista Mexicana de Fisica, No. 59, Vol. 1, 65-76.

Fauziah, R., Abdullah, A. G., \& Hakim, D. L. (2013). "Pembelajaran saintifik elektronika dasar berorientasi pembelajaran berbasis masalah".. INVOTEC, Vol. IX, No.2, 165-178.

Fisher, A. (2009). Berpikir kritis: sebuah pengantar. Jakarta: Erlangga.

Flick, L. B., \& Lederman, N. G. (2006). Scientific inquiry and nature of science. Netherlands: Springer.

Gedgrave, I. (2009). Modern teaching of physics. Chandni Chowk, Delhi: Global Media.

Giancoli, D. C. (2005). Physics principles with applications. USA: Pearson Prentice Hall.

Gillies, R., Ashman, A. F., \& Terwel, T. (2008). The teacher's role in implementing cooperative learning in the classroom. New York: Springer Science+Business Media.

Gronlund, N. E. (1977). Canstructing achievement test, second edition. London: Prentice- Hall Inc.

Hake, R. R. (1999, February 22). Analyzing change. Dipetik June 6, 2014, dari Gain scores: http://www.physics.indiana.edu/ sdi/Analyzin gChange-Gain.pdf

Ibrahim, M. (2014). "Inovasi pendidikan sains dalam implementasi kurikulum 2013". Inovasi Pendidikan Sains dalam Menyongsong Pelakasanaan Kurikulum 2013. Vol. 3, No.1, 1-12.

Ikaningrum, M. N., \& Gultom, T. (2013). "Efektivitas pendekatan scientific inquiry terhadap prestasi belajar dan sikap ilmiah peserta didik". $e$ Journal Universitas Negeri Yogyakarta, No. II, Vol. II, 33-41.

Indriwati, S. E. (2013, Oktober 19). Pendekatan ilmiah harus diterapkan pada semua mata pelajaran. Dipetik Pebruari 3, 2014, dari FPMIPA-BeritaDetail Berita: http://fpmipa.upi.edu/berita/PendekatanIlmiah-Harus-Diterapkan-Pada-Semua-MataPelajaran/0000093.html

Jarvis, P., Holford, J., \& Griffin, C. (2004). The theory \& practice of learning. London: Taylor \& Francis e-Library.

Kagan, D. S., \& Kagan, M. (2009). Kagan cooperative learning. San Clemente: Kagan Publishing.

Kattington, L. E. (2010). Hanbook of curriculum development. New York: Nova Science Publishers, Inc.

Kind, P. M., \& Kind, V. (2007). "Creativity in sScience education: perspectives and challenges for developing school science". ProQuest Education Journals, Volume I, No. 43, 1-37.

Koschmann, T. (2011). Theories of learning ang studies of instructional practice. New York: Springer Science+Business Media. 
Kothari, C. (2004). Reasearch methodology, methods and techniques. New Delhi: New Age International (P) Ltd., Publishers.

Kozulin, A., Gindis, B., Ageyev, V. S., \& Miller, S. M. (2003). Vygotsky's educational theory in cultural context. New York: Cambridge University Press.

Kusmana, S. (2008, Juli 16). Selingkup pendidikan. Dipetik Juni 21, 2014, dari Keterbacaan buku teks pelajaran: http://suherlicentre.blogspot.com/2008/07/kete rbacaan-buku-teks-pelajaran.html

Martin, M. O., Mullis, I. V., Foy, P., \& Stanco, G. M. (2012). TIMSS 2011 international result in science. Boston: TIMSS \& PIRLS International Study Center.

Moore, B. N., \& Parker, R. (2012). Critical thinking. California State University: McGraw_Hill.

Morrison, G. R., Ross, S. M., Kalman, H. K., \& Kemp, J. K. (2011). Designing effective instruction. USA: John wiley \& Sons, INC.

Muallifa, L. (2014). "Implemetasi scientific approach 5 M dalam pembelajaran ikatan kimia kelas X".. Inovasi Pendidikan Sains dalam Menyongsong Pelaksanaan Kurikulum 2013. Vol. 3, No. 53, 278-279.

Mulyasa, H. E. (2013). Pengembangan dan implementasi kurikulum 2013. Bandung: Remaja Rosdakarya.

Nagl, M. G., Obadovic, D. Z., \& Segedinac. (2012). "Effective teaching of physics and scientific method". TEM Journal. No. 2, Vol. 1, 85-89.

Ngadiman. (2013). Tes diagnostik miskonsepsi. Surabaya: Program Pascasarjana, UNESA.

Odja, A. H., Jatmiko, B., \& Supardi, I. Z. (2014). "Model konseptual observasi ilmiah berorientasi kemandirian dalam pembelajaran sains untuk melatihkan keterampilan pemecahan masalah".. Inovasi Pendidikan Sains dalam Menyongsong Pelaksanaan Kurikulum 2013. Vol. 3, No. 3, 15-16.

Ollington, G. F. (2008). Teachers and teaching: strategies, innovations, and problem solving. New York: Nova Science Publishers, Inc.

Pertiwi, D. A., Eny, \& Husna. (2012). "Peningkatan sikap ilmiah siswa melalui metode praktikum dengan pendekatan inkuiri pada materi termokimia”.. Jurnal Program Studi Pendidikan Kimia FKIP Untan. Vol. 4, No. 1, $1-13$.

Phan, H. P. (2010). "Critical thinking as a selfregulatory process component in teaching and learning”.. Psicothema. Vol. 22, No. 2, 284292.

Prunckun, H. (2010). Handbook of scientific methods of inquiry for intelligence analysis. Lanham Maryland: The Scarecrow Press.

Purwono. (2013). "Pembelajaran fisika dengan pendekatan keterampilan proses sains untuk memberdayakan kemampuan berpikir kritis siswa". Peran Sains dalam Abad 21. Vol. 3, No. 56, 318-324.

Pushkin, D. (2007). "Critical thinking and problem solving - the theory behind flexible thinking and skills development". Journal of Science Education. Vol. 8, No. 1, 13-17.

Putra, A. (2013). Penerapan pembelajaran fisika SMA berbasis kegiatan laboratorium. Prosiding Semirata FMIPA Universitas Lampung. Vol. 2, No. 37, 227-233.

Sears, F. W., \& Zemansky, M. W. (1999). Fisika untuk universitas 1 mekanika.panas.bunyi. New York: Addison-Wesley Publishing Company.

Serway, R. A., \& Jewett, J. W. (2010). Physics for scientists and engineers with modern physics. USA: Mary Finch.

Singer, A. J., Murphy, M., \& Hines, S. M. (2003). Teaching to learn, learn to teach. London: Lawrence Erlbaum Associates.

Sujarwanta, A. (2012). Mengkondisikan pembelajan IPA dengan pendekatan scientific. Jurnal Nuansa Kependidikan, No. 1, Vol. 16, 75-83.

Tatsuoka, K. K. (2009). Cognitive assessment: an introduction to the rule space method. New York: Routledge Taylor \& Francis Group.

Tawil, S., \& Cougoureux, M. (2013, Januari 1). UNESCO education research and foresight. Dipetik April 4, 2014, dari Revisiting learning: the treasure within: http://unesdoc.unesco.org/images/0022/002200 /220050e.pdf

Wieman, C. (2007). Why not try a scientific approach to science education? Carnegie Foundation's Centennial Celebration, Vol. 9, No. 2, 9-15.

Wilczenski, F. L., \& Coomey, S. M. (2007). A practical guide to service learning, strategies for positive development in schools. USA: Springer Science+Business Media, LLC.

Williams, J. D. (2011). How science works: teaching and learning in the science classroom. London: Continum International Publishing Group. 